\title{
Constitutional Law and the Teaching of the Parables
}

\author{
Robert A. Burt $†$
}

No one wholly dominates another in a democracy. This central limiting principle in democratic political conflict does more than prohibit imprisonment or murder of political opponents; it also proscribes the total and permanent defeat of opponents' self-defined ideological or economic interests. This constraint has varied expressions in American democratic theory and practice-the assumed permanent existence of some form of opposing political parties, the ideological tenet that respect for minority rights always limits majority rule, and the prohibition of slavery.

There is, however, a problem with this supposed democratic constraint: Some political disputes simply moot it. In some disputes, victory for one side necessarily amounts to total, annihilating defeat for the other-at least as the losers construe that defeat. In this circumstance, democratic principles cannot explain why the loser should accept the legitimacy of his defeat. Even if the loss followed from a majority vote in a popular election, the majority's action would not necessarily attain legitimacy under democratic theory. This is because equality is a bedrock substantive principle of democratic theory and, insofar as the majority is free to disregard the wishes of members of the losing minority and thereby to treat them as less than equals, majority rule is intrinsically at odds with the egalitarian principle. ${ }^{1}$

At the same time, the egalitarian principle does not justify the victory of a minority over a majority of voters simply because the minority believes its vital, non-negotiable interests are defeated. What if the majority believes with equal intensity that its diametrically opposed, vital interests are at stake? The democratic principle of equality cannot identify a winner in

$\dagger$ Southmayd Professor of Law, Yale University. I have been generously helped with this article by Bruce Ackerman, Lee Bollinger, Guido Calabresi, Bob Cover, Don Elliot, Owen Fiss, Paul Gewirtz, Ron Gilson, Henry Hansmann, Jay Katz, Jerry Mashaw, Bob Mnookin, Mark Rose, Adina Schwartz, Tom Shaffer, Mark Sottnick, Alan Weisbard, and Harry Wellington.

1. Equality is formally satisfied in a majority-rule regime since each voter, before votes are cast, has an equal chance to be the decisive vote. See A. Sen, Collective Choice and Social. Welfare 72 (1970); Sen, Social Choice Theory: A Re-examination, 45 Economerrica 53 (1977). But this ex ante equality is not necessarily sufficient comfort in practice or principle after voting for the overridden minority. See M. Shapiro, Law and Polutics In THE Supreme Court 220 (1964) ("Majority rule is . . . [an] expedient . . . but . . . democratically faulty device because it deprives the minority of political equality ... [which] is why the tension between majority rule and minority rights is an inherent feature of democratic thought itself."). 
this dispute. ${ }^{2}$ But more than this, the equality principle dictates that there can be no winner in this dispute.

In practical terms, of course, a winner may emerge. But no matter how much this winner tries to cloak his victory in democratic rhetoric (whether as a "triumph for majority rule" or a "vindication of minority rights"), the underlying logic remains that in disputes where one or both of the parties regards defeat as fundamentally inconsistent with vital interests, enforcing that defeat is a coercive act necessarily at odds with the democratic principle of equality.

The Supreme Court has on many occasions attempted to resolve this logical bind by purporting to give authoritative content to the egalitarian norm and thereby using it to identify a winner in various disputes. ${ }^{8} \mathrm{But}$ as a matter of principle, the Supreme Court's resolutions suffer from the same deficiency that afflicts authoritative resolutions enacted by majoritarian institutions. Both depend for their legitimacy on the existence of an underlying sense of community that unites winner and loser-an acknowledged common identity that transcends the divisive implications of the immediate dispute.

The norm of majority rule implicitly relies on the possibility of some underlying communal identity among winners and losers. Its practical working assumption is that members of the existing electoral majority are not locked in exclusive alliance with one another but that some, at least, are sufficiently prepared to find common ground with the existing minority in order to hold open the prospect of a redefined communal majority in which today's loser becomes tomorrow's winner. In constitutional adjudication, courts similarly rely on an underlying communal identity in their direct appeals to principles that purportedly reflect shared fundamental values. ${ }^{4}$ But where the opposed parties in fact define themselves as

2. See R. Dahl, Dilemmas of Pluralist Democracy: Autonomy vs. Control 90-96 (1982); R. Dahl, A Preface to Democratic Theory 90-119 (1956).

3. See, e.g., Regents of the Univ. of Cal. v. Bakke, 438 U.S. 265 (1978) (special medical school admissions program which sets aside places for minority applicants violates equal protection clause); Frontiero v. Richardson, 411 U.S. 677 (1973) (statute applying gender-based distinctions in calculations of dependency benefits violates egalitarian norm implied by due process clause of Fifth Amendment); Reynolds v. Sims, 377 U.S. 533, 568 (1964) ("The Equal Protection Clause demands no less than substantially equal state legislative representation for all citizens, of all places as well as of all races.").

4. This reliance has recurrently appeared, for example, in the Court's interpretation of the due process clauses of the Fifth and Fourteenth Amendments as expressing "principle[s] of justice so rooted in the traditions and conscience of our people as to be ranked as fundamental," Snyder v. Massachusetts, 291 U.S. 97, 105 (1934), or as forbidding "hardship so acute and shocking that our polity will not endure it," Palko v. Connecticut, 302 U.S. 319, 328 (1937), or as embodying "canons of decency and fairness which express the notions of justice of English-speaking peoples," Adamson v. California, 332 U.S. 46, 67 (1947) (Frankfurter, J., concurring). See also Griswold v. Connecticut, 381 U.S. 479, 501 (1965) (Harlan, J., concurring) (invoking "solid recognition of the basic values that underlie our society"); $c f$. Wellington, The Nature of Judicial Review, 91 YALE L.J. 486, 494 (1982) ("[C]ourts should seek to discover and use the moral ideals of the community as a source of legal 
diametrically and irrevocably opposed to one another, there is no shared communal interest or value-or at least no apparent communal identity to which majoritarian institutions or courts can readily appeal in order to legitimate their resolution of the dispute. These are, in effect, disputes among aliens in which victory for one appears necessarily as total defeat for the other.

In this circumstance, what is the proper role for courts in our constitutional scheme? That is the central question addressed in this article. Two sets of cases will serve as special examples for exploring this question: cases challenging racial segregation and cases challenging institutional treatment of retarded people. In both sets, the litigants see themselves as fundamentally opposed and, more specifically, at odds on the question of whether there is a binding communal relationship between them or whether one side is properly free to refuse association with the other. These cases thus press with particular force against the incapacity of democratic theory to resolve disputes between opponents who acknowledge no mutually binding communal relation, who regard one another as aliens.

\section{I.}

In the years immediately following its decision in Brown $v$. Board of Education, ${ }^{\text {, }}$ the Supreme Court imposed communal bonds between blacks and whites. Thus in 1959, Prince Edward County, Virginia, decided to close its public schools rather than accept integrated education; in 1964, the Court ordered the county to reopen these schools. ${ }^{\circ}$ In 1968 the Court ruled that freedom-of-choice plans in Southern schools were not an adequate means to end segregation; in so holding, the Court required that school boards assign black and white children to the same schools without regard to the expressed wishes of either white or black parents for this mixed attendance. ${ }^{7}$ Again, the Court acted on the premise that blacks and whites were inescapably members of the same community, no matter how fervently members of either race sought to deny this fact. But the Court never stated its reasoning with this stark clarity, and in 1970, the Court began for the first time since Brown to operate on a contrary assumption. In that year, the Court permitted a segregated public park in Macon, Georgia to close rather than to be opened to both blacks and whites. ${ }^{8}$ The

principles.").

5. 347 U.S. 483 (1954).

6. Griffin v. County School Bd., 377 US. 218 (1964).

7. Green v. County School Bd., 391 U.S. 430 (1968).

8. The park property had been given in trust to Macon in 1911 for the use of "white people only"; in 1966 Supreme Court held that the park must be treated as a public institution and opened to both races. Evans v. Newton, 382 U.S. 296, 302 (1966). The Georgia Supreme Court then ruled that "the sole purpose for which the trust was created has become impossible of accomplishment and has 
next year, the Court permitted the city of Jackson, Mississippi to close its public swimming pools for the same reason." These decisions were the first ratification of a newly evolving pattern of race relations: that whites who were unprepared to relate to blacks as equals could choose instead to have no relations with blacks, to secede from any community in which they had common membership.

This secessionist impulse has considerable salience in our political tradition. It received resounding endorsement as an apparently inalienable right in our first national act, our declaration of independence from Great Britain. The document marking that act has a pointed, if ironic, relevance here. The opening words of the Declaration have become so familiar that we have almost stopped hearing them. But listen to them again:

When in the Course of human events, it becomes necessary for one people to dissolve the political bands which have connected them with another, and to assume among the Powers of the earth, the separate and equal station to which the Laws of Nature and of Nature's God entitle them . . . . ${ }^{10}$

Here was the introduction into our political vocabulary of the formula which came to justify the secession of blacks and whites in the South into supposedly "separate but equal" stations."

But this secessionist principle does not stand without contradiction in our past. The Givil War was fought precisely to decide whether some members of a community, by seceding and declaring independence, could free themselves of any obligations to other community members. The question whether, or the extent to which, the War was fought to free slaves is much less clear than the proposition that the War was fought to

been terminated." Evans v. Newton, 221 Ga. 870, 871, 148 S.E.2d 329, 330 (1966). The case was remanded to the state trial court, which granted the motion of the successor trustees that the property revert to the residual legatees. The Supreme Court found no constitutional violation in the state court's enforcement of the reversion. Evans v. Abney, 396 U.S. 435 (1970).

9. Palmer v. Thompson, 403 U.S. 217 (1971).

10. The Declaration of Independence para. 1 (U.S. 1776).

11. The Louisiana statute under review in Plessy v. Ferguson, 163 U.S. 537 (1896), mandated "equal but separate accommodations for the white, and colored races," $i d$. at 540 . The Court gave the phrase no special significance but simply ruled that separate accommodations were not inherently unequal under the Fourteenth Amendment. The phrase was subsequently turned around at the same time that it was elevated to holding in McCabe v. Atchison, T. \& S.F. Ry. Co., 235 U.S. 151 (1914), when the Court reinterpreted Plessy to require that separate facilities be equal in fact. See McCabe, 235 U.S. at 160 ("II]t was not an infraction of the Fourteenth Amendment for a State to require separate, but equal, accommodations for the two races.") (citing Plessy); see also Buchanan v. Warley, 245 U.S. 60, 79 (1917) ("In Plessy $v$. Ferguson, classification and accommodation was permitted upon the basis of equality for both races."); Schmidt, Principle and Prejudice: The Supreme Court and Race in the Progressive Era (pt. 1), 82 Colum. L. Rev. 444, 468-69, 485-94 (1982) (suggesting that $M c C a b e$ was first time Court gave weight to equality side of "separate but equal" equation). 
save the Union and to deny that anyone was free to leave simply as an act of autonomous choice. ${ }^{12}$

There was, however, an enormous cost that followed from the North's insistence that the Union must be preserved. The cost was the most destructive and bloodiest conflict that this nation has ever fought: More than 600,000 men were killed, a larger absolute number and a larger proportion of the total population lost than in any other war America has fought. ${ }^{13}$ The economy of the South was also virtually destroyed and much of its territory left in smoldering ruins. Though hostile ground forces had invaded parts of our country before, they have never done so since, and neither before nor since with such devastation. ${ }^{14}$ The stunning extent of this human carnage and economic destruction set the stage for Plessy v. Ferguson ${ }^{18}$ thirty years later. The Supreme Court in Plessy renounced the fundamental principle for which the Civil War was fought: the principle that people who were joined together in a community could not walk away from that relationship. The Court instead permitted whites to secede from communal relations with blacks by establishing "separate but equal" public facilities. ${ }^{16}$

It is easy today to criticize Plessy. But in order to understand this decision, and to understand its contemporary relevance, we must do more than condemn it as if it were an ancient relic. Plessy was a response to a genuine problem. In one sense the problem came from the incapacity of democratic theory to address diametrical opposition, but the problem was more than theoretical. The social context of Plessy vividly demonstrates the practical political problem that necessarily accompanies this theoretical difficulty: If one member of a community feels such strong hostility to another that he is prepared to break off communal relations, then it is difficult to see how future forced relations can lead to anything but violent

12. On the eve of the Civil War, both Lincoln and the Congress were prepared to disclaim any abolitionist intentions in order to preserve the Union. On March 2, 1861-two days before Lincoln's inauguration and just a month before the bombardment of Fort Sumter-Congress, by two-thirds vote, sent a proposed constitutional amendment to the states that irrevocably protected the institution of slavery. If ratified, it would ironically have been the Thirteenth Amendment. Lincoln explicitly endorsed this proposed amendment in his Inaugural Address. D. PotTER, LincolN and His Party IN THe Secession CRisis 301, 321 (1942); see also D. Donald, Lincoln ReCONSIDERED 209-15 (1961) (discussing various explanations for Civil War); D. POTTER, ThE IMPENDING CRISIS: 18481861, at 44-50 (1976) (discussing relationship of slavery and survival of Union) [hereinafter cited as The IMPENDing CRisis].

13. If the ratio of dead to population had been the same in World War II as that of Southern dead to Southern population in the Civil War, we would have lost five million Americans in World War II, rather than the 384,000 actually killed. T. Williams, That Strange Sad War, in ThE Selected Essays of T. Harry Williams 31, 33 (1983).

14. J. Roark, Masters Wrthout Slaves: Southern Planters in the Givil War and Reconstruction 35-108 (1977); C. VanN WoOdWARd, Origins of the New SOUTH, 18771913, at 107-12 (2d ed. 1971).

15. 163 U.S. 537 (1896).

16. Sep supra note 11. 
conflict. Thus, the principle of secession appears at its simplest level to be justified as a way of avoiding violent conflict between those with diametrically opposed interests. This was the perception-the apparent political problem-that led the Supreme Court to abandon the Givil War amendments in Plessy $v$. Ferguson. ${ }^{17}$

This problem of apparently irresolvable, potentially violent political conflict also framed - and was, I believe, an underlying impetus for-the Supreme Court cases beginning in 1970 that accepted the principle of secession in relations between blacks and whites. These were years of extraordinary convulsions produced by our involvement in the Vietnam War, closely following the widespread race riots of the 1960's. Though this secessionist impulse has not yet utterly dominated the Supreme Court's race cases, it is at work in all of the cases and in different Justices' opinions with different degrees of intensity and clarity. ${ }^{18}$

The secession issue is, moreover, not limited to racial segregation cases. It is also visibly at stake in the Court's recent cases involving institutions for retarded persons. These cases appear to reflect a wish on the part of normal people to dissociate themselves from retarded people, and thus they also mirror the emergence of the so-called "white backlash" since Brown. But more than this, the Court's majorities in these cases repeatedly rely on a constitutional norm of "state autonomy." The invocation of that norm signifies the rising dominance of a narrowly individualistic, secessionist impulse for all manner of contemporary social relations. ${ }^{19}$

17. See generally C. VANN WOODWARD, supra note 14, at 350-56 (dramatic and violent deterioration of race relations accompanied transition from "slavery system" to "caste system" by late 19th century).

18. See, e.g., City of Mobile v. Bolden, 446 U.S. 55 (1980) (plurality opinion by Stewart, J.) (in absence of showing of intentional racial discrimination, at-large electoral system does not violate Constitution); Columbus Bd. of Educ. v. Penick, 443 U.S. 449, 489 (1979) (Rehnquist, J., dissenting) (system-wide desegregation remedy inappropriate in absence of affirmative acts of racial discrimination by local school board); id. at 479 (Powell J., dissenting) (where segregated school systems not product of intentional government action, system-wide desegregation orders inappropriate and counterproductive); Village of Arlington Heights v. Metropolitan Hous. Dev. Corp., 429 U.S. 252 (1977) (Powell, J.) (proof of discriminatory intent necessary to show constitutional violation by locality in denying rezoning application necessary to build racially integrated housing project); Milliken v. Bradley, 418 U.S. 717, 745 (1974) (Burger, C.J.) (absent finding that racially discriminatory acts of school districts or state "have been a substantial cause of interdistrict segregation," district court could not order interdistrict desegregation remedy).

19. In the days of Plessy, this impulse was also spread across the face of the Court's work. This was most openly expressed in the Court's hostility to labor organizations whose underlying premise was that workers had a continuing stake in their employment relationship notwithstanding an employer's wish to end (or unilaterally to dictate the terms of) that relationship. See In re Debs, 158 U.S. 564 (1895); A. Paul, Conservative Crisis and the Rule of law: Attitudes of Bar and BENCH, 1887-1895, at 83-88, 119-22 (1960).

This secessionist vision of economic relations was also, though less obviously, expressed in the Lochner series of cases, where the Court refused to permit a majority in legislative forums to impose terms on the employment relation. The Court instead demanded deference to the principle that employer and employee approach one another as isolated individuals who might choose to relate or not, and to relate on any terms for which they alone might contract. Lochner v. New York, 198 U.S. 45 (1905); 
In Halderman v. Pennhurst State School and Hospital, ${ }^{20}$ the district judge found that the very existence of a large-scale, geographically isolated residential institution violated the constitutional rights of its retarded residents. ${ }^{21} \mathrm{He}$ therefore ordered the institution closed and required the state to provide alternative community residences with therapeutically homelike settings. ${ }^{22}$ The Third Circuit essentially affirmed this order, though it based its holding on a congressional act rather than directly on constitutional norms. ${ }^{23}$

During oral argument of the case in the Supreme Court, several Justices pressed the question whether the state was free simply to close its institutions and provide no assistance whatsoever to retarded people. ${ }^{24}$ This issue was not directly posed in the case itself, since the state sought only to run its institutions without judicial supervision; nor did the Court's opinion directly address this issue. But in overturning the Third Circuit's reading of the congressional statute, Justice Rehnquist's majority opinion set out the general proposition that the Constitution gives great weight to the principle of state autonomy and that states must accordingly have great latitude to allocate or to refuse resources as they see fit. Rehnquist therefore concluded that congressional impositions must be narrowly construed in light of this constitutional imperative. ${ }^{25}$ The Court's praise for the principle of state autonomy suggested its willingness to uphold the action of any state that might ultimately refuse to provide any assistance to retarded people. ${ }^{28}$

This was made more explicit in Youngberg $v$. Romeo, ${ }^{27}$ decided the succeeding term. Romeo involved the same state institution as Pennhurst, though this suit was not a class action seeking wholesale institutional closure but was instead an individual action by one resident who claimed constitutional violations in the institution's failure to protect him from abuse and to provide him with training programs. The Court ruled that the state was constitutionally obligated to provide at least "minimally ade-

see also L. TRIBE, AMERican Constitutional. LAw 434-42 (1978) (discussing Lochner progeny).

20. 446 F. Supp. 1295 (E.D. Pa. 1977), aff'd in part and rev'd in part, 612 F.2d 84 (3d Cir. 1979), rev'd, 451 U.S. 1 (1981).

21. Id. at 1318.

22. Id. at 1326-28.

23. Halderman v. Pennhurst State School \& Hosp., 612 F.2d 84, 104-07 (3d Cir. 1979) (Developmentally Disabled Assistance and Bill of Rights Act establishes preference for community rather than institutional residence for retarded people), rev'd, 451 U.S. 1 (1981).

24. See Transcript of Oral Argument at 75-81, Pennhurst State School \& Hosp. v. Halderman, 451 U.S. 1 (1981).

25. Pennhurst State School \& Hosp. v. Halderman, 451 U.S. 1, 16-17 (1981).

26. The Court invoked a ghost of Lochner by characterizing federal-state relations as "contractual" so that "[t]he legitimacy of Congress' power to legislate under the spending power thus rests on whether the State voluntarily and knowingly accepts the terms of the "contract." 451 U.S. at 17.

27. 457 U.S. 307 (1982). 
quate training" to an institutionalized retarded person. But the Court made clear, in an opinion by Justice Powell, that this obligation arose only because the state had chosen to make this person "wholly dependent on the State" by placing him in an institution; the Court observed that "[a]s a general matter, a State is under no constitutional duty to provide substantive services for those within its border."28

Both Romeo and Pennhurst involve more than the question whether states must share communal tax resources with retarded people. They raise the issue whether others are inescapably obliged to regard retarded people as members of their community. The district court order in Pennhurst requiring community residential placement addressed this issue quite directly. But even the claim for an institution-based training program in Romeo had a similar implication; its premise was that without training, Nicholas Romeo would persist in violent and bizarre conduct that frightened others and prompted them to abuse and to isolate him. In both cases, the retarded people claimed a right to acknowledged inclusion in a wider community, with the proviso that this inclusion was possible only if the "normal" members of that community made a special, and especially expensive, effort to include them.

Retarded people can cast this claim in "autonomy" terms: The refusal of others to include them inhibits the development of their full individual capacities and interferes with their freedom to choose association with normal people. ${ }^{29}$ But put in these terms, there is an obvious rejoinder: Retarded people's wishes to associate are inconsistent with others' wishes to refuse this association. Thus put, these cases raise the thorniest underlying problem of the racial segregation cases at the time Brown was decided.

The problem appeared in two forms. The first was the question of the efficacy of any judicial remedy: If either blacks or whites did not want to associate, how could courts force them into association with any hope of fruitful results? ?30 $^{30}$ (This same question of efficacy is raised regarding court-ordered community residences for retarded people. ${ }^{31}$ ) The second

28. Id. at 317.

29. See generally J. Gliedman \& W. Roth, The Unexpected Minority: Handicapped ChILDREN IN AMERICA 221-37 (1980) (discussing undesirability of separating handicapped school children from peers).

30. Justice Jackson alluded to this concern in an unpublished memorandum that he may have intended as the draft of a concurrence in Brown: "[Whether the] real abolition of segregation will be accelerated or retarded by what many are likely to regard as a ruthless use of federal judicial power is a question that I cannot and need not answer." Quoted in R. KLuger, SIMPLE JuSTICE 688 (1975).

31. For instances of community resistance to association with retarded people, see New York State Ass'n for Retarded Children v. Carey, 466 F. Supp. 486 (E.D.N.Y. 1978), aff'd, 612 F.2d 644 (2d Gir. 1979) (rejecting public health rationale offered by school board for segregating retarded children); Comment, Deinstitutionalizing the Mentally Retarded in Maine: The Inevitable Face-off with Zoning, 35 ME. L. REv. 33 (1983). 
question was one of principle, of freedom of choice. Even assuming that racial segregation laws interfered with the freedom of blacks to choose association with whites, what principle could justify forcing unwilling whites into the company of blacks?

This was the proposition from which Herbert Wechsler, the most prominent academic critic of Brown, built his case in $1959 .{ }^{32}$ Wechsler argued that these diametrically opposed associational wishes meant that there were no subsuming "neutral principles" available to resolve this controversy..$^{3 s}$ Having construed the dispute in these terms, Wechsler was correct in seeing it as dilemmatic. ${ }^{34}$ But he drew a non sequitur from this observation. He argued that this dilemma rendered courts specially unfit to resolve the controversy and required them to defer to majoritarian institutions. In effect, he argued that this dilemma afflicted courts more than other institutions because courts are specially obliged to act on principle while majoritarian institutions are free from this constraint..$^{35}$

There is a limited validity to this argument: Majoritarian institutions are free to fashion many principles of action from whole cloth, to make "policy choices" inappropriate for courts. But this special freedom adheres to majoritarian institutions only because their actions rest on underlying, implicit communal bonds between majority and minority. In controversies such as these involving racial segregation or institutionalization of retarded people where communal bonds are adamantly denied, this source of legitimation is not available to majoritarian institutions. ${ }^{36}$

32. Wechsler, Toward Neutral Principles of Constitutional Law, 73 HARv. L. REv. 1 (1959).

33. Id. at 34.

34. A different construction of the system of racial segregation was more plausible in the social circumstances of the pre-Brown South. Rather than refusing association, whites wanted it but insisted that blacks remain permanently subordinate in that association. See Black, The Lawfulness of the Segregation Decisions, 69 YALE L.J. 421, 424 (1960). But though Wechsler may have misconstrued Southern whites' intentions and thus erred in his criticism of Brown, his basic theoretical premise remains correct. This premise, moreover, has more accurate descriptive relevance to contemporary race relations than to relations in the late 1950 's. See infra pp. 478-79.

35. Wechsler, supra note 32 , at 19.

36. Some commentators, most notably John Hart Ely, have argued that courts can properly intervene only to police the processes of majoritarian institutions in order to assure that all disputants have appropriate access. See J. ElY, DemocracY and DisTrust (1980). This process limitation does not, however, adequately address the problem of principle presented by these disputes. The problem is not in process; full access to participate in a majority decision would not solve it. The problem is that the disputing parties have diametrically opposed definitions of the community in which they claim membership: One party excludes the other from any communal relation while the other demands inclusion. Courts cannot restrict their attention to the process by which this substantive dispute will be addressed because both the substantive and procedural aspects of the dispute depend on defining communal membership. In another sense, the dispute is jurisdictional: Is one who chooses to secede nonetheless properly subject to the coercive authority of majoritarian institutions? For related criticisms of attempts to restrict judicial review to process concerns, see Brest, The Fundamental Rights Controversy: The Essential Contradictions of Nornative Constitutional Scholarship, 90 YALE L.J. 1063, 1092-95 (1981); Fiss, The Supreme Court, 1978 Tern-Foreword: The Forms of Justice, 93 Harv. L. REv. 1, 6-11 (1979). 
Wechsler's critique also ignores the historical fact that the Civil War marked the repudiation of the secessionist principle and that the Givil War Amendments gave federal courts a central role in enforcing the terms (and thereby implicitly the fact) of that repudiation. Even before these events, the Supreme Court had claimed for itself a special role in refuting the secessionist principle and protecting the indissolubility of the national community. The Court had assumed, most notably in McCulloch v. Maryland $^{37}$ and Dred Scott $v$. Sandford, ${ }^{38}$ that it could accomplish this role by definitively resolving disputes that might otherwise lead to disunion. ${ }^{30}$ This pretension was of course exploded in the immediate wake of Dred Scott, but its underlying imperative survived the war. The imperative survived because the contradiction in democratic theory could not be eradicated; democratic theory cannot identify a legitimate winner in intense, diametric disputes.

Though all of our governmental institutions attempt in various ways to obscure this contradiction - to soften its sharp edges and somehow to lead warring parties toward a consensual accomodation-a special role has devolved on the Court simply because of its alluring availability as a forum of last resort for persistent dissidents. The Court cannot resolve this contradiction any more than can other institutions. The Court can, however, dramatize this contradiction more powerfully and even more menacingly than other institutions. It does this, sometimes self-consciously and sometimes not, in the very format of constitutional litigation.

Here is the recurrent drama. Adversaries fight, and not simply regarding trivial matters, but about the content of the fundamental charter of the country; they fight and then the Justices announce the true content, which ends the fight. Or does it? What if the losing party resists? And what if

37. 17 U.S. (4 Wheat.) 316 (1819).

38. 60 U.S. (19 How.) 393 (1856).

39. See Chief Justice Marshall's prologue in McCulloch:

In the case now to be determined, . . . [t] he constitution of our country, in its most interesting and vital parts, is to be considered; the conflicting powers of the government of the Union and of its members, as marked in that constitution, are to be discussed; and an opinion given, which may essentially influence the great operations of the government. No tribunal can approach such a question without a deep sense of its importance, and of the awful responsibility involved in its decision. But it must be decided peacefully, or remain a source of hostile legislation, perhaps, of hostility of a still more serious nature; and if it is to be so decided, by this tribunal alone can the decision be made.

17 U.S. (4 Wheat.) 316, 400-01 (1819); see also Dred Scott v. Sandford, 60 U.S. (19 How.) 393, 454-55 (1856) (Wayne, J.; concurring) ("The case involves private rights of value, and constitutional principles of the highest importance, about which there had become such a difference of opinion, that the peace and harmony of the country required the settlement of them by judicial decision.").

A similar conception of the judiciary's peace-making role appears implicit in Chief Justice Warren's retrospective observation regarding his Court's racial relations work: "[T]he vast majority of people must realize by now that racial equality under law is basic to our institutions and that we will not and cannot have peace in our nation until the race issue is properly settled." E. WARREN, THE Memoirs of Earl WarRen 293 (1977). 
that losing party has greater apparent force than the Court can command? What if the losers are the majority force in the political institutions, the majority whose actions the Court has now declared unconstitutional? Will the majority in the states, in the Congress, through the Presidency, acquiesce in the Court's judgment, or will they fight openly; and if the majority fights, will the Court find powerful allies anywhere?

The salience of these questions in any action by the Supreme Court-and their special force when the Court invalidates the act of a majoritarian institution on constitutional grounds-is loud testimony to the fragility of our institutions: to their fragility in fact, because dissension can so readily persist among unrepentant losers and can so readily obstruct peaceful processes, and to their fragility in principle because diametric conflicts cannot be resolved on the basis of democratic theory. In its symbolism and in its structure, the Supreme Court through constitutional litigation vividly shows how easily political conflict becomes transformed into diametric opposition regarding the fundamental tenets of our society and how such opposition can lead thus to the brink of civil war-and, in the typical case, we all back away from that abyss.

In this demonstration, the Court plays a role different from the majoritarian institutions. It is misleading, however, to characterize this judicial role as distinctively coercive or nonconsensual but to describe the majoritarian institutions as grounded on democratic principle. The Court and its processes are more visibly nonconsensual-speaking more explicitly in an authoritarian voice, invoking coercion more openly-than the processes of the majoritarian institutions. But judicial review is not thereby, as Alexander Bickel claimed, a "deviant institution in the American democracy" 40 because majoritarian institutions rest on popular consent while the Court does not. The Court instead reveals a quintessential characteristic of all American political institutions because it, more than the others, shows the fragility of communal bonds in democratic theory and practice. The Court, more than other institutions, points to the substratum of coercive force that necessarily lies beneath relations between people who might otherwise be divided by deep-rooted antagonisms. The Court does differ from the other institutions-not in kind but only in the clarity with which it shows the practical and principled affliction of all democratic institutions.

Skeptics of judicial authority deduce from this affliction that there is no role for courts in the face of it. Thus, in a widely cited dictum, Learned Hand maintained that

40. A. Bickel, The least Dangerous Branch: The Supreme Court at the Bar of Pourrics 18 (1962). 
[A] society so riven that the spirit of moderation is gone, no court can save; that a society where that spirit flourishes no court need save; that in a society which evades its responsibility by thrusting upon the courts the nurture of that spirit, that spirit in the end will perish. ${ }^{41}$

Judge Hand raises here an issue separate from, and prior to, the question of principle regarding the judicial role posed by Professor Wechsler and elaborated by Professor Bickel. Judge Hand's claim is methodological: that there is no way for courts in the face of divisive disputes to achieve a spirit of moderation or the underlying communal bond that is the basis for such spirit, and that without such spirit and bond, these disputes are irresolvable. I believe, however, that the gravitational pull specially exerted on deeply divisive disputes by courts in our institutional scheme, coupled with their palpable weakness in imposing effective force on the disputing parties, gives courts a pedagogic advantage over other institutions that Hand failed to appreciate. This advantage does not assure practical success. But once we have grasped the virtues of this methodology uniquely available to courts in confronting diametrically opposed disputants, we can approach the questions of principle that follow: whether courts may properly invoke these methods and, even more fundamentally, whether and when they are obliged to do so.

We can address the methodological issue by considering in some detail a pedagogic tradition that, at first glance, may seem unsuited to any court. The tradition is in the New Testament parables which teach that everyone may choose to become a member of the same community. ${ }^{42}$ From this it follows that no one may unilaterally exclude another from the communal relation; each is accordingly obliged to treat others with equal regard (to observe the Golden Rule or the "spirit of moderation," as Judge Hand would put it).4 Jesus' use of these parables in this pursuit is certainly not a clear example of practical enforcement success. Nor do I invoke this precedent as direct proof that courts are morally obliged to make this effort regardless of its likely success. Rather, these parables represent a pedagogic methodology that is also available, and distinctively available, to

41. L. Hand, The Contribution of an Independent Judiciary to Cizilization (1942), reprinted in The SPIRIT OF Libirty 181 (I. Dilliard ed. 1959).

42. Sep E. Schili.ebeeckX, Jesus: An Experiment in Christology 249-56 (1979).

43. Jesus emphasized the pre-eminence of this obligation:

Then one of the lawyers . . . came forward and asked him, "Which commandment is first of all?" Jesus answered, "The first is, 'Hear, O Israel: the Lord our God is the only Lord; love the Lord your God with all your heart, with all your soul, with all your mind, and with all your strength.' The second is this: 'Love your neighbour as yourself.' There is no other commandment greater than these."

Mark 12:28-32 (New English). 
courts because of their institutional characteristics.

II.

The Constitution is a secular document that purports to derive its authority from popular sovereignty. The initial authoritative act establishing the binding force of that document has so far receded in our past, however, that it often seems more like an oracular, even a divine, act than an ordinary secular event. The special posture of judges, as remote blackrobed protectors of the document, adds to its sanctified aura. There are, therefore, parallels between the secular authority of the Constitution in the polity and the divine authority of the Gospels in religious belief, and between the exegetical role of judges and of priests and prophets.

There is a further, presentational similarity between the Gospels' teachings and the pages of the United States Reports. In both settings, the claim for authority often appears apodictic, assumed rather than argued for, and deference thus seems commanded rather than requested. Yet this appearance is often contradicted: Reasons for compliance are given and dependence on voluntarily proffered obedience is admitted. Thus in both settings there is a conjunction of claimed unquestionable authority and admitted weakness to command obedience.

In the Gospels, the parable of the prodigal son illustrates the method Jesus used to refute what I call the secessionist principle and to teach the lesson of community. The narrative outline of the parable is familiar. A father divides his wealth between his two sons; the younger son takes his share away from the family home and squanders it, then returns impoverished and feeling disgraced. But the father welcomes him joyously, arranges a homecoming feast and proclaims to everyone, "[L]et us eat and make merry; for this my son was dead, and is alive again; he was lost, and is found." 44

But what of the elder son and his attitude? What kind of burden did the return of this younger prodigal put on him? Why should he welcome this return? The parable continues:

Now [the] elder son was in the field; and as he came and drew near to the house, he heard music and dancing. And he called one of the servants and asked what this meant. And [the servant] said to him, "Your brother has come, and your father has killed the fatted calf, because he has received him safe and sound." But [the elder son] was angry and refused to go in. His father came out and entreated him, but he answered his father, "Lo, these many years I have served you, and I never disobeyed your command; yet you never gave me a kid,

44. Luke 15:23-24 (Revised Standard). 
that I might make merry with my friends. But when this son of yours came, who has devoured your living with harlots, you killed for him the fatted calf!" And [his father] said to him, "Son, you are always with me, and all that is mine is yours. It was fitting to make merry and be glad, for this your brother was dead, and is alive; he was lost and is found."45

The parable ends here; we are not told whether the elder brother was persuaded by his father's injunction to join in the rejoicing. But this question, it seems to me, is the crucial aspect of the story. Why should the elder brother rejoice? Is it because the father has ordered him to rejoice, has invoked his superior authority? And is the further implicit message that Jesus in telling the parable has invoked his extraordinary authority, his divine authority, to establish the correctness of the father's command that we should all rejoice?

But here is a practical difficulty, a paradox. How does anyone order "rejoicing"? Grudging acquiescence, perhaps, can be ordered, but not joy. Yet it is joyfulness, merrymaking, that the father enjoins. He cannot expect the elder son to comply-to feel joy, to "make merry and be glad"-unless his words have touched a deeper feeling already in the elder brother's heart. Then the elder son would also find joy in his younger brother's return-joy that when he was "in the field," at a distance, he had not recognized in himself.

Perhaps the elder brother did not feel this; perhaps he never would join in the rejoicing. The parable ends without resolving this doubt. The possibility remains that the elder son would simply reiterate his question, "Why did you disfavor me? Why have I been wronged?" This dramatic indeterminacy could have its own impact on the listeners whom Jesus addressed in telling the parable. If they identified themselves with the faithful elder son, betrayed by his father's attention to the undeserving prodigal, then Jesus' substantive message would be as much lost on them as on the elder son in the parable itself. The parable, that is, holds open the possibility for continued dispute between Jesus and his listeners as well as between the father and his elder son.

This does not seem incidental or unintended. The Gospels make clear the importance of the parables' open texture. This was suggested quite self-consciously when the disciples specifically asked Jesus why he spoke in parables to the crowds gathered to hear him. Jesus replied:

To you the secret of the kingdom of God has been given; but to those who are outside everything comes by way of parables, so that (as

45. Ild. $15: 25-32$. 
Scripture says) they may look and look, but see nothing; they may hear and hear, but understand nothing; otherwise they might turn to God and be forgiven. ${ }^{46}$

This is a puzzling explanation. Why should the parables intentionally conceal their meaning? But this is not the least puzzle in this purported explanation. Jesus also distinguished between "those who are outside," for whom the parables are apparently designed to mystify, and his disciples, the quintessential insiders, to whom "the secret of the kingdom of God" has been given. But having drawn this distinction, Jesus immediately confounded it; for he asked his disciples, "You do not understand this parable? How then are you to understand any parable?"47 Jesus then proceeded to explain, to decode, the parable. But the underlying message was clear that if the disciples had been true insiders, true recipients of the divine secrets, then no such elaborate explanation would have been required.

By this account, the parables are not intended to be readily accessible to any listener. ${ }^{48}$ They are designed to raise questions more than to answer them, to confound rather than to confirm prior understanding, and particularly to accomplish this in order to raise doubts among their listeners about whether they are among the elect or remain outside among those who "hear and hear, but understand nothing."

The parable of the prodigal son itself makes this point. The elder son had regarded himself as faithful "these many years" to his father's commands and thus more worthy than his erring brother, but the father confounded this apparently reasonable expectation. Jesus told the parable in response to a challenge to his own similar unconventional conduct: "And the Pharisees and the scribes murmured, saying, "This man receives sinners and eats with them." "49 Again, the purpose is to confound insiders and outsiders, to unsettle those who are confident of their rectitude. But it was not enough for Jesus simply to say this. He tried to dramatize this proposition for his listeners; he tried not simply to exhort them from a distance but to draw them in to experience unexpected self-doubt.

The strategy in all this is not simply to confound or to raise self-doubts for their own sake; the strategy is to heighten the listeners' sense of their own vulnerability. This is shown, though with typical paradoxical indi-

46. Mark 4:11-12 (New English).

47. Id. 4:13.

48. Sep F. Kermode, The Genesis of Secrecy: On the Interpretation of Narrative 23-47 (1979); E. SCHIL.I.EBEECKX, supra note 42, at 155-58. Regarding an apparently similar "narrative technique of studied reticences . . . [and] significantly patterned ambiguities" in the Old Testament, see R. Alter, The ART of Biblical NarRative 126, 153-59 (1981).

49. Luke 15:2 (Revised Standard). 
rection, in the parable that immediately precedes the story of the prodigal son, the parable of the shepherd and the lost sheep. Jesus offered this parable as his initial response to the challenge "murmured" by the selfrighteous scribes and Pharisees:

What man of you, having a hundred sheep, if he has lost one of them, does not leave the ninety-nine in the wilderness, and go after the one which is lost, until he finds it? And when he has found it, he lays it on his shoulders, rejoicing. And when he comes home, he calls together his friends and his neighbors, saying to them, "Rejoice with me, for I have found my sheep which was lost." Even so, I tell you, there will be more joy in heaven over one sinner who repents than over ninety-nine righteous persons who need no repentance. ${ }^{50}$

This parable repeats the central oddity that the story of the prodigal son presents: Why should a father, why should heaven, rejoice more for one repentant sinner than for those who "need no repentance"? And was it fair or sensible for the shepherd to abandon the ninety-nine sheep "in the wilderness" in order to seek out the lost one?s1

Here again, the parables confound insider and outsider. The shepherd's action in abandoning the ninety-nine sheep in effect converts all of them into lost sheep; all of them become vulnerable and none can count on the continued presence and strength of the shepherd for protection. And here is the basic strategy for teaching the lesson of community. Jesus did not teach this lesson only by speaking on behalf of sinners, of the weak, of outcasts; he did more than argue their case to the righteous, the strong, the insiders. He argued that there are none but outsiders. He asserted that there are no righteous people without need to repent, there are no faithful elder sons, there are no sheep but those who are lost. And thus the central oddity of these parables disappears. Who are these "ninety-nine righteous persons who need no repentance?" There are none. Who, hearing the parables and choosing to listen, can be confident that he is among this "ninety-nine"?

From this premise alone, Jesus offered hope: the possibility of finding a way inside through acknowledgement of vulnerability. He offered this hope through the father who welcomes his prodigal son (as we are all prodigals), the shepherd who searches for his lost sheep (as we are all lost). Even more compellingly, he offered this hope in his own life: the outcast, scorned and crucified, who is received joyously by his Father in heaven and is reborn; as with the prodigal son, who "was dead, and is

50. Id. 15:3-7.

51. See Erikson, The Galilean Sayings and the Sense of "I", 70 YALE REv. 321, 353 (1981). 
alive again; . . . was lost, and is found."

This is the message of hope, of reassurance; but how much hope can it reliably give? What power stands behind it to make good on its promise? There is no easy answer to these questions in the New Testament Gospels; and it is not the point of the Gospels to give an easy answer. Their point is to portray the urgency of the questions; no one can take for granted that he is safely inside some protected flock, that he is found. Once this possibility is admitted, once an individual believes so deeply in his own vulnerability, it is of course tempting to believe even more deeply, more urgently, that salvation is available, that a protecting father with unquestionable authority and power is at hand. But if provoking this temptation is the underlying goal of these parables' teachings, they do not pursue this directly. The parables do not undertake to demonstrate the truth of this particular answer. The parable of the prodigal son in particular makes clear that the father's authority is insufficient to obtain the result he wants from his elder son. All that the father's authority can command-but this it clearly can command-is a hearing for his point of view. The father can command his elder son to listen to the lesson but not to obey it. This is the first step of the methodology of the parable. The father can command a hearing because he and his elder son stand in a pre-existing relationship of hierarchical authority. But this is only the first step. How does the father convert the opportunity provided by his procedural capacity to obtain a hearing into joyful acceptance of his substantive lesson? The underlying goal-and the basic methodology of all of these parables-is to lead the listeners to acknowledge a question, not an answer: a question about the true extent of their own safety. The premise of this methodology is that when the listeners acknowledge their vulnerability, they will see the appeal of the answer that Christ represents. The parables in effect only teach the proper question so that, once taught this, the true initiates teach themselves the proper answer.

\section{III.}

What is the lesson in all of this for judicial conduct in our secular society? Again, the first part of the lesson is methodological. Judicial invocation of the Constitution recurrently uses the same methods as these parables: converting all into needy outsiders by confounding insider and outsider and then offering hope for ultimate protection by mapping a path back inside for everyone.

The clearest example of this method in recent times, and perhaps in the entire history of the Court, is the series of racial segregation decisions 
beginning with Brown v. Board of Education. ${ }^{52}$ In these cases, until at least 1970, the Court's use of the methodology of the parables was virtually explicit and self-conscious. Ultimately I will argue that this methodology dominates the work of the Court whether or not the Justices prefer or acknowledge it. The imperative for this methodology arises from the internal contradiction in democratic principle that I identified at the outset, in the incapacity in principle or practice of democratic institutions to resolve disputes between diametrically opposed parties. The argument will emerge most clearly if we begin with instances where the Justices did not resist this imperative but embraced it.

Brown was such an instance. The Court confounded both insider and outsider by placing its power at the service of outcast blacks, by identifying the Constitution with the cause not simply of ending their enslavement but of ending their exclusion from equal intercourse with all others. In the metaphor of the parable, this was the Court as shepherd leaving the self-satisfied flock to find the lost sheep. The second step I have sketched-that the flock was thereby converted into needy outsiders-was only implicit in Brown, but it became resoundingly explicit four years later in Cooper v. Aaron. ${ }^{\text {ss }}$

The Governor of Arkansas, Orville Faubus, ordered state troops to bar black students from attending Central High School in Little Rock. The Supreme Court proclaimed that Faubus's action was war against the Constitution; ${ }^{\text {s4 }}$ that his action endangered the "maintenance of our federal system of government"; $;$ that Faubus was in effect an unjustified rebel, an anarchist, an outsider to the American community who threatened its integrity and who would remain outside, excommunicated, until he repented. At the same time the Court offered a route for return: submission to its authority. The question of Faubus's willingness to include blacks in his community was thus transformed-as in the parable of the prodigal son by the father's injunction to his eldest son-into the question of Faubus's willingness to submit to a higher authority who had chosen to embrace a previous outsider, an outcast.

The Court did not, however, explicitly offer Faubus an option to refuse submission; nor did the parables offer this option in their terms. Indeed, the Court in Cooper v. Aaron enunciated the most emphatic demand for unquestioning obedience in its entire jurisprudence:

Article VI of the Constitution makes the Gonstitution the "su-

\footnotetext{
52. 347 U.S. 483 (1954).

53. 358 U.S. 1 (1958).

54. Id. at 18 .

55. Id. at 4 .
} 
preme Law of the Land." In 1803, Chief Justice Marshall, speaking for a unanimous Court, referring to the Constitution as "the fundamental and paramount law of the nation," declared in the notable case of Marbury v. Madison, 1 Cranch 137, 177, that "It is emphatically the province and duty of the judicial department to say what the law is." This decision declared the basic principle that the federal judiciary is supreme in the exposition of the law of the Constitution, and that principle has ever since been respected by this Court and the Country as a permanent and indispensable feature of our constitutional system. It follows that the interpretation of the Fourteenth Amendment enunciated by this Court in the Brown case is the supreme law of the land, and Art. VI of the Constitution makes it of binding effect on the States "any Thing in the Constitution or Laws of any State to the Contrary notwithstanding." Every state legislator and executive and judicial officer is solemnly committed by oath taken pursuant to Art. VI, cl. 3, "to support this Constitution." Chief Justice Taney, speaking for a unanimous Court in 1859, said that this requirement reflected the framers' "anxiety to preserve it [the Constitution] in full force, in all its powers, and to guard against resistance to or evasion of its authority, on the part of a State . . ." Ableman v. Booth, 21 How. 506, 524.

No state legislator or executive or judicial officer can war against the Constitution without violating his undertaking to support it. Chief Justice Marshall spoke for a unanimous Court in saying that: "If the legislatures of the several states may, at will, annul the judgments of the courts of the United States, and destroy the rights acquired under those judgments, the constitution itself becomes a solemn mockery . . . " United States v. Peters, 5 Granch 115, 136. A Governor who asserts a power to nullify a federal court order is similarly restrained. If he had such power, said Chief Justice Hughes, in 1932, also for a unanimous Court, "it is manifest that the fiat of a state Governor, and not the Constitution of the United States, would be the supreme law of the land; that the restrictions of the Federal Constitution upon the exercise of state power would be but impotent phrases . . . Sterling v. Constantin, 287 U.S. 378, 397-398. ${ }^{.8}$

I cite this passage at such length for several reasons. It poses first of all a question of audience: For whom is it written? This passage suggests the same paradoxical answer that Jesus gave his disciples about his parables: that the Court speaks both to insiders and outsiders and it speaks in order to mystify both, though in different ways. For outsiders the mystification is apparent: a parade of historic figures (Marshall, Taney, Hughes), a flurry of mysterious citations (Art VI; cl. 3; 5 Cranch; 21 How. and the

56. Id, at $18-19$. 
like), all with the implication that the Court's majesty, its claim to be taken seriously, is enhanced thereby.

But for those who already take or want to take this authority seriously, for those who see themselves as disciples or aspire to that status, this passage raises a deeper puzzle. Such insiders would know Chief Justice Taney and Ableman v. Booth: Taney the author of the notorious Dred $S$ cott $^{\mathbf{5 7}}$ decision entrenching slave status and Ableman $v$. Booth, ${ }^{\mathbf{5 8}}$ overriding Northern states' efforts to withhold alleged runaway slaves from their Southern masters. This invocation of Taney and Ableman says to knowledgeable insiders that fealty to the Constitution means submission to the Court regardless of one's own judgment concerning the propriety of the Court's demand. The reference in this passage to Chief Justice Hughes in 1932, just before his Court struck down important New Deal legislation, ${ }^{59}$ carries the same implication. To question the Court is, by this passage, to misunderstand its authority under the Constitution, to move outside the constitutional community.

A similar conclusion is implicated by Jesus' sharp rejoinder to the disciples who questioned him: "You do not understand this parable? How then are you to understand any parable?"80 By these equivalent statements of Jesus and of the Court, to be a true disciple of either, a true insider, requires the transcendence of one's ordinary critical faculties, an act of faith. How then does one become or remain an insider, according to these directives? By a mystifying process indeed; even by a self-mystifying one.

To admit this is to raise a question about the power of Jesus or of the Court to secure obedience in practice. The admission raises this question because this kind of command (to believe, to have faith) seems fundamentally not amenable to external enforcement. Jesus in his ministry openly admitted this proposition. He had no armed force at his command, and he repeatedly refused to invoke the apparently awesome divine power that some allege him to have had; indeed, he chastised his disciples for advocating this invocation. ${ }^{61}$ Jesus' death-mocked by others and even apparently plagued, momentarily at least, by his own doubts ${ }^{62}$-made his weakness extraordinarily vivid.

57. Dred Scott v. Sandford, 60 U.S. (19 How.) 393 (1856).

58. 62 U.S. (21 How.) 506 (1858).

59. See Carter v. Carter Coal Co., 298 U.S. 238 (1936) (overturning Bituminous Coal Conservation Act of 1935); United States v. Butler, 297 U.S. 1 (1936) (overturning Agricultural Adjustment Act of 1933); Schechter Poultry Corp. v. United States, 295 U.S. 495 (1935) (overturning National Industrial Recovery Act of 1933).

60. Mark 4:13 (New English).

61. Luke 9:51-56; Matthew 26:51-54, 4:5-10, 16:21-23.

62. Mark 15:34. 
Justices of the Supreme Court might not so readily withhold invocation of whatever awesome power they could muster; the declamatory rhetoric in Cooper v. Aaron is not the voice of the meek. But whatever they might prefer, the Justices have little choice in this matter. The Court is, as many have observed, "the least dangerous branch," without direct power to command "the sword or the purse." tices are without power. It does mean that, when their power is directly and adamantly challenged, they cannot protect themselves by their independent acts; they are dependent on others' acts of faith, of good faith toward them.

The immediate context of Cooper v. Aaron itself makes this clear. A full year before that decision, President Eisenhower had sent federal troops into Little Rock to countermand Governor Faubus's action. Neither the Supreme Court nor any lower court had ordered this presidential action. As a matter of constitutional doctrine it was agreed then (and remains virtually as clear in the Gourt's cases even today) that judges had no authority over the President for such directives. ${ }^{84}$ Nonetheless the President did not portray his actions as voluntary; when he sent the troops, he stated that "[o]ur personal opinions about the [Brown] decision have no bearing on the matter of enforcement." ${ }^{285}$ The President thus presented himself as a model of the true believer in the Court's power; he ostentatiously purported to suspend his own critical faculties; he displayed his faith by submitting to the Court's will notwithstanding his power to disobey.

For the legal cognoscenti, moreover, the President's power to disobey was more than a practical reality. As constitutional head of a separate, coequal branch, the President could have plausibly claimed authority not to deploy the troops that the Court needed to enforce its will. Eisenhower may have seen himself as free in principle to ignore the Court's wishes, but may have decided for political reasons to hide his own volition in sending troops behind the screen of obedient submission to the Court. ${ }^{66}$ But whether he saw himself as true believer or merely calculated that it was expedient for him to masquerade as one who believed in the Court's

63. Alexander Hamilton originated these phrases in the Federalist papers. See THE Federalst No. 78, at 490 (A. Hamilton) (B. Wright ed. 1961).

64. Sep McKay, "With All Deliberate Speed": A Study of School Desegregation, 31 N.Y.U. L. Rev. 991, 1076-77 (1956) (President has discretion regarding use of armed forces to enforce court decrees); ff. United States v. Cox, 342 F.2d 167, 171 (5th Gir.) (separation of powers dictates that courts may not direct Attorney General to initiate criminal prosecutions), cert. denied sub nom. Cox v. Hauberg, 381 U.S. 935 (1965).

65. Radio-television address by President Eisenhower (Sept. 24, 1957), reprinted in B. MuSE, Ten Years of Preilude 141 (1964).

66. See E. WARREN, supra note 39, at 289, 291-92 (Warren's acerbic evaluation of Eisenhower's failure to avow his own agreement with Brown). 
authority, the symbolic point remains the same: Because knowledgeable observers know that the Court's commands are never self-executing, each command carries with it an implication of the Court's vulnerability, of its dependence on others. The Court is more obviously dependent on enlisting the cooperation of others-of outsiders-than are the other institutions in our government. Thus, whether the Justices admit it or not, like it or not, every action of their institution carries the same fundamental implication confounding insider and outsider, confounding strong and weak, conveyed by the parables.

The Justices rarely admit to this weakness. But this is why Cooper $v$. Aaron is an extraordinary decision in the Court's jurisprudence. The crisis regarding its own authority, and regarding the rule of law in this country, that the Justices palpably saw in Governor Faubus's defiance brought their weakness into unaccustomed visibility at the same moment as-even because-the Justices were making a transcendent claim to command obedience.

The Justices' weakness appeared in Cooper v. Aaron in the very way that they spoke, even before they began speaking. The tradition established by John Marshall was that the Court asserted its collective force by uniting behind a single Justice who "delivered the opinion of the Court." Though there was a majority endorsing a single opinion (indeed, the holding was unanimous), no one Justice spoke for the Court this time. Cooper v. Aaron instead began this way: "Opinion of the Court by The Chief Justice, Mr. Justice Black, Mr. Justice Frankfurter," and so on, listing each individual Justice by name. ${ }^{88}$ The Justices may have believed that this unprecedented way of emphasizing their unity would enhance the appearance of strength in the Court. Whatever their intent, however, this manner of speech inevitably personalized the institution, highlighting the fact that, after all, these were nine men speaking.

The Justices also emphasized their vulnerability, again perhaps unintentionally, at the very end of their opinion in another unprecedented action. They unanimously reaffirmed the Court's original decision in Brown, though none of the litigants had suggested or even anticipated that the Court might re-examine that decision. The Justices explained their reasons for this unusual action in this final paragraph in Cooper $v$. Aaron:

The basic decision in Brown was unanimously reached by this Court

67. See G. Gunther, Cases and Materials on Constitumional Law 504 (10th ed. 1980) ("John Marshall persuaded his colleagues to abandon seriatim opinions.").

68. 358 U.S. at 4. 
only after the case had been briefed and twice argued and the issues had been given the most serious consideration. Since the first Brown opinion three new Justices have come to the Court. They are at one with the Justices still on the Court who participated in that basic decision as to its correctness, and that decision is now unanimously reaffirmed. The principles announced in that decision and the obedience of the States to them, according to the command of the Constitution, are indispensable for the protection of the freedoms guaranteed by our fundamental charter for all of us. Our constitutional ideal of equal justice under law is thus made a living truth. ${ }^{69}$

The Court thus united behind the original principle of Brown. But it could take this stance only by overcoming the potential vulnerability caused by the absence of three Justices who had participated in Brown. ${ }^{\text {io }}$

In the body of their opinion in Cooper $v$. Aaron, the Justices proclaimed, as I recited earlier, that the "federal judiciary is supreme in the exposition of the law of the Constitution" and that from this proposition "[i]t follows that the interpretation of the Fourteenth Amendment enunciated by this Court in the Brown case is the supreme law of the land."7x Whatever the force of this syllogism in principled or practical terms, the final paragraph in Cooper $v$. Aaron implicitly admits that the syllogism does not apply to new Justices on the Court, that they are not bound in unquestioning obedience toward the Justices who preceded them. They are not bound unless, of course, they choose to bind themselves as the new Justices did in the final paragraph of Cooper $v$. Aaron.

The new Justices' voluntary submissions, acts of faith, thus gave strength and extended life to the will of the old Justices. This renewal, and the implicitly acknowledged vulnerability of the Court to the prospect of new Justices willing to repudiate the old, testified not only to the uncontrollable political forces that always stand behind, waiting to undermine, the Court's claim for power to command obedience. This reaffirmation of Brown also spoke in simple personal terms to the Court's vulnerability because it was composed of men who might fall weary and resign, of men who might die.

This implication of the Court's unanimous reaffirmation shares an underlying similarity with the substantive message of the parables: the ideal of community not simply as a morally worthy pursuit but as a haven from chaos, from personally vulnerable isolation, from the prospect of death itself. In the parables, the sheep returns to the flock, the prodigal son to

69. Id. at 19-20.

70. Justice Jackson had died and was replaced by Justice Harlan; Justices Minton and Reed had resigned and were replaced by Justices Brennan and Whittaker.

71. 358 U.S. at 18. 
his family home: Each "was dead, and is alive; . . . was lost and is found."72 The Justices portrayed their own unanimity and reaffirmation of common purpose in this same life-giving sense: "[O]ur constitutional ideal of equal justice under law is thus made a living truth." ${ }^{\text {"73 }}$ In the parables, the communitarian ideal is meant to point beyond the secular world. The vision in the race cases remains secular. But in both instances, the communitarian ideal promises safety.

This is the substantive message that arises from the methodology shared by the parables and race cases. Their method, their pedagogic technique, is first to command the attention of people who conceive themselves as safely inside some protective flock; then to persuade these people that they are no different from others visibly outside, even others whom they believe they have excluded from their own safe superiority; and, finally, having provoked in these once-smug insiders feelings of vulnerability and consequent empathic identification with the old outsiders, to show how this empathy in itself can serve as the route for membership in a community that promises a more reliable, more secure haven.

IV.

Unlike the New Testament, neither the substantive message of community nor the methodology of provoking special sympathy for outcasts is pervasively characteristic of Supreme Court jurisprudence. Indeed, as I suggested earlier, the powerful force of secessionism as a respected principle in our political tradition appears to point the other way. Although Brown stands against the secessionist principle, we may now be in the process of abandoning opposition to this principle just as we did in the generation that followed the Civil War. And for the same reason: because the costs of communal relations appear-at least to one party-excessive and frightening, filled with apparently unresolvable conflict and potential for violence. We may today be drawing distinctions between some blacks and whites who share common ground, and others who are divided by residence, by income, by family structure, by prospects for employment, and who, from this viewpoint, have so little in common that they are not members of the same community. ${ }^{74}$ This is the meaning of the stunningly

\footnotetext{
72. Luke 15:32 (Revised Standard).

73. 358 U.S. at 20 .

74. In 1968, the National Advisory Commission on Civil Disorders, convened by President Johnson in the wake of widespread race riots, observed: "Our nation is moving toward two societies, one black, one white-separate and unequal."' NAT'L Advisory CoMM'N ON CiviL. Disorders, REPORT 1 (1968). This ominous movement has continued:

The gap between the average incomes of whites and blacks is as wide today as it was in 1960 , primarily because the proportion of black families headed by women rose from one-fifth to nearly one-half and the proportion of black men with jobs dropped sharply in that period
} 
and disproportionately high rates of black unemployment, ${ }^{78}$ particularly in urban areas where more and more blacks are congregating. The old assumption had been that blacks were always needed at least to do the most menial tasks, the dirty work in the society, but even this assumption apparently does not hold now. The massive unemployment of blacks reflects the tenuousness of this old assumption and its implicit link of interdependence, of a bondage between blacks and whites, a community bond that once apparently could not be broken. ${ }^{26}$

Despite this evident impetus toward secessionism, however, a considerable conceptual and practical problem prevents it from attaining the status of a right. ${ }^{77}$ Even though the cost of maintaining a relationship appears excessive to one party, and leads him to proclaim his independence of the other, nonetheless the cost of breaking off that relationship may seem excessive and therefore wrongful to the putatively abandoned party. The latter's claim for a continuing relationship can take many forms. It can rest on a notion of equity that comes from weighing comparative burdens-as from the perspective of retarded people who will be utterly helpless and destitute, shut away in their own world if the wider community does not somehow include them. The claim can rest on past interactions with implications that cannot be cancelled by a unilateral act of will-as from the perspective of black people who see themselves unfairly shut away from community resources to which they had earlier made disproportionate, uncompensated contributions. Whatever the components of these different calculations of cost between the seceder and seceded, how can these different calculations be sensibly compared?

To put the question in this way is to ask whether there is a single community in which these disputants remain members: not necessarily a community in which they embrace one another's company, but a community of discourse, of common meanings, in which their conflicting interests

... Fourteen percent of white families with children under 18 are headed by women, while 47 percent of black families are in that category, up from 8 percent in 1950 and 21 percent in 1960.

The problem is compounded . . . by the fact that only 55 percent of black men over the age of 16 are employed today, as against 74 percent in 1960.

Herbers, Income Gap Between Races Wide as in 1960, Study Finds, N.Y. Times, July 18, 1983, at A1, col. 2, A8, col. 1 .

75. The unemployment rate in October 1982 was $9.3 \%$ for whites, $20.2 \%$ for blacks, and $15.2 \%$ for Hispanics. Spe Pear, Bias Blamed for High Minority Jobless Rates, N.Y. Times, Nov. 24, 1982, at B6, col. 4. The United States Commission on Civil Rights found that the differences in unemployment rates increased in the 1970's "as the burdens of the mid-decade recession fell heaviest on minorities and women." Id.

76. Writing in 1944, Gunnar Myrdal saw the first indications of this increasing trend toward social and economic distance between the races. See G. MYrdal, An American Dilemma: The Negro Problem and Modern Democracy 380-82, 582-99, 647-62 (1944).

77. For consideration of the uncertain status of a "right to secession" in international law, see $L$. Buchheit, Secession: The Legrtimacy of Self-Determination 20-137 (1978). 
and perceptions can be described in comparable terms, thereby identifying a single calculus of costs and benefits. Unless such a community of discourse exists, how can a third party, a judge, stand between these two conflicting parties and adjudicate their conflict in terms that take adequate account of both apparently incommensurable perspectives? This question in effect asks whether the underlying grammar, the deep structure, of a vocabulary of rights demands some shared understanding, and therefore some kind of consensuality, among all people to whom that vocabulary can properly apply. ${ }^{78}$

Lurking behind this conceptual problem is an urgent practical problem. Effective withdrawal from communal relations depends in many circumstances on the acquiescence of both parties, not simply on the will of one. This acquiescence need not be voluntary on both sides, but it must be purchased somehow, and as a practical proposition, coercion by itself is a flawed instrument for this purpose. Contemporary race relations vividly make the point. If wealthy whites want to stand on the principle of autonomous withdrawal from poor urban blacks in the face of black demands for resource redistribution, and if whites cannot obtain voluntary submission by blacks to the force of this secessionist principle, then whites must create armed enclaves for themselves and never venture outside except under heavy guard and in daylight. ${ }^{79}$ This way of life is hardly an expression of the calm self-confidence that an autonomous individual expects to enjoy, that the principle of secession means to claim. There is precious little self-determination in these white redoubts; their residents are instead hostage to the intentions (and even worse, to the fearfully imagined rapacious intentions) of those excluded from access to the hoarded resources.

This is a starkly drawn picture of contemporary race relations. It is not wholly accurate, though it corresponds to imagery regularly invoked in popular media. It is not wholly accurate because, if it were, social repose of any sort would have long ago vanished; if substantial numbers of

78. See B. Ackerman, Social. Justice in the Liberal State 349-78 (1980); K. ARrow, Soctal Choice and Individual Values 74-91 (2d ed. 1963); Cover, The Supreme Courl, 1982 Term-Foreword: Nomos and Narrative, 97 HARv. L. REv. 1 (1983).

79. Some have already taken such defensive actions:

[There is] a select but growing number of small and often remote cities whose citizens have chosen to live behind walls.

In these cities, access to the gated areas is gained only by a variety of security measures. . . .

"There's a real trend toward gating off in California," said Fred Christensen, a public management consultant.

....

Golden Beacn [Florida], population 612 , is a small strip seven miles up the sand from Miami Beach. Two years ago, access to the community was restricted by means of a central guard station and gate on the main road....

[The City Manager] said the reason for the move was an obvious one: "Security. We're not that far from Miami."

Some Rich Touns Being Walled Off, N.Y. Times, June 27, 1983, at A12, col. 4. 
blacks-just thousands, say, among the millions living in comparative poverty in urban areas-chose to define themselves as terrorists with no stake in the preservation of existing entitlements, there is no practically effective coercive force available to the targeted whites to guarantee repose. The application of coercive force might protect the lives and property of most whites. But this force could not exorcise the fears of these whites, their nightmare sense of vulnerability that would haunt every waking and sleeping hour. Nor, in this imagined community, would blacks' lives be models of calm repose. They too would be increasingly subject to random and ferocious retaliation because of the fear that they inspired. Fearful whites, unable reliably to distinguish between "friendly" (that is, adequately submissive) poor blacks and resentful black terrorists, would increasingly define all poor blacks as fearsome terrorists. All poor (and many rich) blacks in turn would increasingly define themselves in this way because they could not escape, and there would be no advantage to them in trying to escape, this white fear-imposed definition.

This is not contemporary American society, but it is a recognizable version of it. This was Southern slave society-at least as revealed in the occasional nightmare confessionals of the Founding Fathers who held slaves and of some Southern gentry who presided over the institution of slavery at later times. ${ }^{80}$ It is not a comfortable vision. It is a vision of inevitable interdependence and of equality at least in one sense: of the equal capacity of virtually any individual to make life a nightmare, a hell on earth, for all others.

The Supreme Court's action in Brown implicitly evoked this vision; the unanimous reaffirmation of Brown in the final paragraph of Cooper $v$. Aaron vividly recalled this vision in the Justices' admission of their own interdependence, ${ }^{81}$ by choosing to yoke themselves together and thereby in effect to depend on their shared strength or (which is the same thing) to

80. See, e.g., L. Litwack, Been in the Storm So Long: The Aftermath of Slavery 59-63 (1979); The IMPENDING CRIsis, supra note 12, at 451-55. Mary Chesnut described the climate of fear among whites in 1862 after Betsey Witherspoon, Mrs. Chesnut's cousin, was murdered by her own slaves:

Hitherto I have never thought of being afraid of negroes. I had never injured any of them. Why should they want to hurt me? . . . Somehow today I feel that the ground is cut away from under my feet. Why should they treat me any better than they have done Cousin Betsey Witherspoon?

[My sister] Kate and I sat up late and talked it all over . . . .

Kate's maid came in-a strong-built mulatto woman. She was dragging in a mattress. "Missis, I have brought my bed to sleep in your room while Mars David is [away] at Society Hill. You ought not to stay in a room by yourself these times." And then she went off for more bed gear.

"For the life of me," said Kate gravely, "I cannot make up my mind. Does she mean to take care of me-or to murder me?"

Mary Chesnut's Givil War 199 (C. Woodward ed. 1981) (emphasis in original).

81. See supra p. 477. 
hold one another hostage. The Court of this era spoke to this sense of interdependence in its general solicitude to visible outcasts-to criminal defendants ${ }^{82}$ and prisoners, ${ }^{83}$ to political dissenters, ${ }^{84}$ to illegitimate children $^{85}$ and atheists, ${ }^{86}$ to an array of outsiders who could be considered "discrete and insular minorities"87 especially deserving of judicial solicitude. The Court may have acted to include these quintessential outsiders to safeguard the rest from the consequences of their disaffection. The Court may have assumed that these outsiders could easily be incorporated into the American "mainstream" because of the Justices' belief in its capaciousness and resiliency, their confidence that no one need be excluded in order to protect insiders from any threat. ${ }^{88}$ Whatever the Justices' motives, however-whatever the urgency of the threat they perceived from unrepentant dissenters in our democracy-the possibility of disruption always exists.

The Supreme Court is not obliged to admit this openly. An open admission indeed might increase rather than allay anxiety; it might only tempt dissenters by alerting them to their own disruptive strength or provoke insiders to preemptive repression against dissenters by alerting them to the fragility of their current comfort. These are questions of pedagogic strategy, questions that no one can readily answer. ${ }^{88}$ But it is important to

82. See Miranda v. Arizona, 384 U.S. 436 (1966) (persons taken into police custody must be given statement of rights prior to interrogation).

83. See Griffin v. Illinois, 351 U.S. 12, 20 (1956) (state must provide transcripts of trial to indigent criminal defendants planning appeal).

84. See Watkins v. United States, 354 U.S. 178, 198-99 (1957) (congressional committees may not unjustifiably encroach on privacy of persons thought to be associated with Communist Party).

85. See Levy v. Louisiana, 391 U.S. 68 (1968) (invalidating discriminatory wrongful death statute which denied illegitimate children right of recovery).

86. See School Dist. v. Schempp, 374 U.S. 203 (1963) (prohibiting state from requiring prayer in public schools).

87. The phrase is from United States v. Carolene Prods. Co., 304 U.S. 144, 152 n.4 (1938).

88. Justice Frankfurter wrote this in an unpublished file memorandum during the Court's deliberations on Broum:

The outcome of the Civil War ... is that there is a single American sociely. Our colored citizens . . . are not . . . to be denied the right to grow up with other Americans as part of our national life. And experience happily shows that contacts tend to mitigate antagonisms and engender mutual respect.

Quoted in R. KLuger, supra note 30, at 684. A contemporary Presidential Commission agreed with Frankfurter's assertion about the salutary effects of interracial contact:

[Recent] experiences demonstrate that segregation is an obstacle to establishing harmonious relationships among groups. They prove that where the artificial barriers which divide people and groups from one another are broken, tension and conflict begin to be replaced by cooperative effort and an environment in which civil rights can thrive.

President's Comm. on Civil Rights, To Secure These Rights 82-83 (1947); $c$. R. HofStadter, The Progressive Historians 438 (1970) ("Somewhere around 1950 . . . conflict as a vitalizing idea began to be contested by the notion of a pervasive American consensus.").

89. The Court's attention to this issue of pedagogic strategy was apparent in one particular detail of its opinion in Cooper v. Aaron, 358 U.S. 1 (1958). An early draft prepared by Justice Brennan set out Marbury r. Madison as "establish[ing] the basic principle that the federal judiciary is supreme in the exposition of the law of the Constitution." Quoted in Hutchinson, Unanimity and Desegregation: 
acknowledge that principle does not bar Supreme Court Justices from answering one way or the other. In particular, democratic principle does not require the Court to remain aloof from these questions, leaving them to majoritarian institutions.

Thus, when Herbert Wechsler suggested that conflict between blacks who wanted integration and whites who wanted segregation could not be resolved in principle, ${ }^{90}$ he was correct. But Wechsler was wrong to draw from this premise the conclusion that courts were therefore disabled from addressing this conflict. The correct conclusion is that because the diametric, irreconcilable opposition between the parties mooted the application of democratic principle, majoritarian institutions could not legitimately resolve this dispute. These institutions did purport to resolve it: Segregation laws were duly enacted by majority vote. But these laws were illegitimate because this diametrically opposed dispute could not be resolved by institutions organized on the basis of democratic principle. The Supreme Court was justified on this ground in invalidating these laws. ${ }^{91}$

This justification for overturning legislation has apparently limitless potential application. Every litigant who chooses to challenge the constitutionality of a law in effect presents this justification on the face of his complaint. Notwithstanding this common rhetorical posture, however, every instance of constitutional litigation does not in fact reflect diametric

Decisionmaking in the Supreme Court, 1948-1958, 68 Gro. L.J. 1, 80 (1979). The draft opinion then added that "[t]his decision was not without its critics, then and even now, but it has never been deviated from in this Court. The country has long since accepted it as a sound, correct and permanent interpretation." Id.

Even this minimal legitimation of, and apparent invitation for, criticism of the Court did not survive into the final version of this passage in the Court's opinion, which reads: "This decision declared the basic principle that the federal judiciary is supreme in the exposition of the law of the Constitution, and that principle has ever since been respected by this Court and the Country as a permanent and indispensable feature of our constitutional system." 358 U.S. at 18.

The Court returned to this identical issue later that Term, but this time in a little-noticed case addressing the jurisdiction of state courts over commercial transactions on Indian reservations. Justice Black, writing for a unanimous Court, offered this historical exegesis on the relationship between popular criticism and judicial authority:

Around 1830 the Georgia Legislature extended its laws to the Cherokee Reservation despite federal treaties with the Indians which set aside this land for them . . . . The constitutionality of these laws was tested in Worcester $v$. Georgia, 6 Pet. 515 . . . Rendering one of his most courageous and eloquent opinions, Chief Justice Marshall held that Georgia's assertion of power was invalid....

Despite bitter criticism and the defiance of Georgia which refused to obey this Court's mandate in Worcester the broad principles of that decision came to be accepted as law. Over the years this Court has modified these principles... but the basic policy of Worcester has remained.

Williams v. Lee, 358 U.S. 217, 218-19 (1959) (footnotes omitted). According to Justice Black's clerk that Term, Justice Frankfurter returned his draft copy of the opinion in this case with the notation, "I agree with etiery word, including the essay on Brown v. Board of Education." Interview with Guido Calabresi, Sterling Professor of Law, Yale Univ. (Feb. 15, 1983) (notes on file with author).

90. Wechsler, supra note 32 , at 34 .

91. See pp. 461-66. 
opposition of sufficient depth and intensity to raise doubts about the willingness of one party to remain in a consensual communal relation with the other, which would thus justify judicial intervention.

But even this formulation of a judgmental standard has extensive potential applicability in constitutional litigation. Deciding which dispute warrants judicial intervention by the standard suggested here should not rest on a judge's personal preference for one disputant over others, but neither can it rest on the application of clear-cut impersonal criteria that wholly guard against this possibility. The decision for judicial intervention ultimately must rest on an elusive criterion: the importance of the dispute, either because of its general social signification or its intense urgency to some few who are directly affected by it. Judges can give this criterion sensible content only if they are passionately engaged in their contemporaries' concerns and, at the same time, impartial (or, perhaps more accurately, encompassingly compassionate) toward all of the disputants who bring the conflicting facets of those concerns into court.

The elusiveness of this formulation is reason enough for some to reject it on the ground that the proper occasions for the exercise of judicial authority must be clearly and rigorously limited in order to assure its unquestioned legitimacy..$^{92}$ But such rejection rests on a false premise if, as I have argued, the proper purpose of judicial intervention is to signify that the dispute at hand is so deeply divisive as to moot the applicability of basic democratic principles. From this perspective, judicial authority cannot depend on unquestionably legitimate authority. The very purpose of judicial intervention in these circumstances is visibly to call into question the legitimacy of all constituted authority, including the court's own authority, with regard to the dispute at hand.93

92. See, e.g., Bork, The Impossibility of Finding Welfare Rights in the Constilution, 1979 Wasr. U.L.Q. 695, 697-98; Bork, Neutral Principles and Some First Amendment Problems, 47 IND. L.J. 1 (1971).

93. Michael Perry fails to grasp this proposition in his recent effort to formulate a rationale for judicial activism. M. Perry, The Constitution, the Courts, and Human Rights (1982). He posits a "prophetic" function for courts "designed to enable the American polity to live out its commitment to an ever-deepening moral understanding." Id. at 101. But because he assumes that democratic theory demands primacy for electorally accountable institutions, Perry finds himself caught in a contradiction between his conception of moral leadership for judges and the apparently superior authoritative claims of majoritarian institutions. Id. at 125-26. Perry resolves this contradiction by finding that the Constitution gives clear-cut authority to Congress to silence federal courts, including the Supreme Court (and probably even state courts) by withholding jurisdiction from them. Id. at 128-32. In practical terms, Perry thereby trivializes his conception of a transcendent judicial role. In theoretical terms, Perry does not see that the legitimacy of this congressional power cannot be resolved by reliance on democratic theory. In disputes of great historic moment, when Congress is most likely to be sufficiently aroused to give serious consideration to this retaliatory withholding of court jurisdiction, democratic theory cannot justify the victory of one political disputant over another or the primacy of one institution (legislature or court) over the other. The historically persistent doctrinal stalemate over the question of Congress' jurisdiction-withholding authority, id. at 132-33, is an apt reflection of this stalemate in democratic principle. 


\section{Teaching of the Parables}

Intervention for this purpose does not permit a court to impose its own resolution on the disputing parties. A court can only say-but this it must say-that the dispute in its current posture cannot legitimately be resolved and that accordingly the particular resolution, the legislative enactment, that one party has imposed on the other is invalid. This is the proper limit of judicial authority in invalidating legislation. ${ }^{94}$ This is, in final analysis, all that Brown did. The Court overturned the extant race segregation laws but did not dictate the scheme that would replace them; Brown II purposefully held back from this imposition..$^{95}$ The Court was not prepared to demand immediate compliance or to define the precise terms of compliance until $1968,{ }^{96}$ and by then events of considerable significance had intervened. In political terms, Southern defenders of the segregation regime had been dramatically isolated and even shamed by the unprecedented amassing of two-thirds of the Senate to override filibusters against the Civil Rights Acts of 1964, 1965, and 1968. ${ }^{97}$ (The 1968 Act was particularly notable because its "fair housing" title applied more directly to Northern patterns of race prejudice than to its Southern embodiments. ${ }^{98}$ ) Moreover, the Supreme Court itself had been extraordinarily transformed between 1955 and 1968 by the changed status of Thurgood Marshall from advocate for the scorned racial minority to member of the Court. ${ }^{99}$

None of these actions was commanded by the Court; none of them could have been. Nor could the Court have forced Southern blacks to act at risk to their very lives in demanding satisfaction-actions echoed by President Johnson's promise that "we shall overcome" when he asked

Perry's basic error is in seeking to legitimize judical review by identifying principles for hierarchically ranking the relative authority of judicial and majoritarian institutions. $\mathrm{He}$ has distinguished company in the commission of this error; it has been the dominant theme of constitutional law scholarship at least since James Bradley Thayer, id. at 17-18.

94. Conventional remedies doctrine expresses this limitation in the general rule that judges are barred from correcting constitutional flaws they find in state or federal laws but must instead simply invalidate the offending laws. See O. Fiss, Injunctions 416 (1972); Starr, Accommodation and Accountability: A Stralegy for Judicial Enforcement of Institutional Reform Decrees, 32 AL.A. L. REv. $399,425-26$ (1981). This doctrine is one aspect of a more general conception requiring that judges not impose their own resolution on disputes underlying constitutional litigation but instead restrict themselves to reopening the disputes invalidly resolved in majoritarian institutions. See Burt, The Constitution of the Family, 1979 Sup. Cr. REv. 329, 357, 378-79.

95. Brown v. Board of Educ., 349 U.S. 294 (1955).

96. Green v. County School Bd., 391 U.S. 430 (1968); see G. Gunther, supra note 67, at 765-69.

97. Thus when cloture was first voted in 1964, only seven Senators outside the South voted against cloture: Goldwater and Hayden of Arizona, Young of North Dakota, Bible of Nevada, Mechem of New Mexico, Byrd of West Virginia, and Simpson of Wyoming. 110 Cong. REc. 13,327 (1964).

98. S. Lubel.l, White and Black: Test of a Nation 140-45 (rev. ed. 1966); Hauser, Demographic Factors in the Integration of the Negro, 94 DAEDalus 847, 850-53 (1965).

99. Justice Marshall was appointed to the Court in 1967; he had been appointed to the Court of Appeals for the Second Circuit by President Kennedy in 1962 and had resigned in 1965 to become Solicitor General at President Johnson's appointment. 
Congress to enact the Voting Rights Act of $1965 .^{100}$ The Court could and did both command attention for these claims and identify the moral ideal of community upon which these claims rested. But the Court could not force the satisfaction of these claims - not only, and not even most significantly, because it lacked the practical strength to mobilize this force. The Court could not force this result because forced commitment to this moral principle is self-contradictory; it is in itself a defeat for the principle.

This is also the lesson taught by the parables. They teach that communal membership cannot be commanded by any force, no matter how divine or seemingly omnipotent. Forced love is a contradiction in terms, a reign of terror ${ }^{101}$ But this is not the true force of the parables I have explored. Forced attention to the truth of interdependent communal membership and to the consequent urgent need for genuine communal fellowship-this is the pedagogic method of these parables. Jesus invoked this method to convey the substantive message of the need for divine salvation and to overcome the easy impulse toward smug self-satisfaction, to refute the secessionist error.

This error is not the secular lesson of the Declaration of Independence, the supposed fount of the secessionist principle in our political tradition. I cited the famous first sentence of the Declaration earlier, but only its introductory phrase. ${ }^{102}$ The full sentence completes its message, the most important part of which I omitted:

When in the Course of human events, it becomes necessary for one people to dissolve the political bands which have connected them with another, and to assume among the Powers of the earth, the separate and equal station to which the Laws of Nature and of $\mathrm{Na}$ ture's God entitle them, a decent respect to the opinions of mankind requires that they should declare the causes which impel them to the separation. ${ }^{103}$

Here is the heart of the Declaration and of the role of the Supreme Court in our society: the obligation to explain one's reasons, to acknowledge in this way a continuing communal relationship even if the explanation itself is offered as an attempt to justify refusing any closer or more enduring ties. With this obligation to explain comes a reciprocal obligation to listen, and thus the possibility that at least a common language

100. See R. Evans \& R. Novak, Lyndon B. Johnson: The Exercise of Power 496 (1966).

101. The Gospels' teachings have occasionally been distorted to this end. Thus, witness the holy crusades and the infliction of terrible cruelty in Jesus' name; the New Testament suggests that Jesus himself, though only momentarily, succumbed to this tendency. Luke 22:35-38.

102. See supra p. 458.

103. The Declaration of Independence para. 1 (U.S. 1776). 
will emerge from this discord. Through discourse, the antagonists may thus discover or uncover or rediscover their common humanity, ties that truly bind them together notwithstanding their divisive conflicts.

Courts in our society should accordingly insist that, if conflict arises, neither party quickly or automatically severs all relations. And even if one party does conclude that the cost of a continuing relationship is so burdensome that it must break all ties, nonetheless that party must explain this reasoning and must at least listen to the other party's assertion that the costs of secession are so great, that this party's need and desire for a continuing relationship are so powerful, that the seceder should reconsider and affirm their enduring commonality. This process of explanation and justification is not simply process for its own sake. It is process with a substantive goal of teaching that anyone who withdraws from relations with others must have a good reason for withdrawal that these others should acknowledge and respect.

This pedagogic goal has two facets. The first is to provide occasions for mutual recognition of previously unsuspected or denied empathic identification with others' needs. Judicial process can press this identification into realization by imposing a course of dialogic engagement, of intensive conversation and confrontation. This is the hope and promise of the pedagogic methodology of the parables.

The second facet is to vindicate the rule of law. In these fundamentally divisive disputes, the rule of law is challenged because the disputes call into question the existence of a shared and therefore mutually coherent vocabulary of rights and duties. Yet without this common language, this community of discourse, there is no way to talk meaningfully about mutual obligations, even the obligation peacefully to respect one another's wish to be left alone, to secede from communal relations.

Without this common language, therefore, one party's wish to withdraw is merely the prelude to warfare (either open or covert but smolderingly explosive) and there is no reason in principle that either party can offer to avert this prospect. If, however, one pursues the claim to secede not simply as a matter for brute imposition of force but instead as a claim of right, the process of explanation and justification can transform this claim into a mutual acknowledgement of communal obligations. This is the one basic underlying communal bond that judges in our society can legitimately command in order to vindicate the coherence of the rule of law.

Dialogic engagement provides the means to create mutual meaning on which the rule of law depends. Because this engagement is the precondition for developing the capacity for meaningful exchange, it is incoherent in principle to constrain the dialogue by limiting a priori its substantive 
terms or the identity of the participants. Even the substantive premise of equality, a bedrock democratic principle, is not a directive with specific prior content. ${ }^{104}$ Equality is itself an idea with content that emerges and changes over time through the process of dialogic exchange, a process that courts can properly initiate and guide but not authoritatively conclude. Thus the question, for example, whether fetuses or profoundly retarded people or animals are equal participants in this social dialogue, with consequent claims to full-fledged substantive entitlements, cannot coherently depend on some a priori application of the notion of equality or of dialogue itself. ${ }^{105}$ Of course, social dialogue depends on interpersonal communication. But if fetuses speak to me in ways that you cannot hear, that does not mean that your deafness defines the permissible (or the actually present) participants in the dialogue between us. I see three participants and you see two: On what common principle do we count? ${ }^{108}$ The answer must be that we cannot count; we can only talk until an agreed calculus emerges or we agree to disagree or one of us is prepared to accept the consequences of walking away even without an agreement that the argument has ended.

And where does this dialogic process end? On what basis can one secede from this conversation? There are perhaps practical answers to this question: invoking superior coercive force to impose silence on an opponent, or enforcing physical distance by a unilateral move across some frontier. But I see no end in principle, except a mutually agreed end. And even the practical argument for the termination of dialogue, for secession, in order to avoid irresolvable conflict is unconvincing for reasons that Lincoln set out in his inaugural appeal to the South on the eve of the Civil War:

Can aliens make treaties easier than friends can make laws? Can treaties be more faithfully enforced between aliens than laws can among friends? Suppose you go to war, you cannot fight always; and when, after much loss on both sides, and no gain on either, you cease fighting, the identical old questions as to terms of intercourse are again upon you. ${ }^{107}$

Lincoln's words did not persuade. And the force he then invoked to preserve a communal bond led to no mutually agreed end but only to

104. See Karst, Why Equality Matters, 17 GA. L. Rev. 245 (1983) (ideal of equality has had different meanings in different eras).

105. See B. ACKerman, supra note 78, at 69-103.

106. The Supreme Court wrongly held itself to be the authoritative calculator in this dispute in Roe v. Wade, 410 U.S. 113 (1973); see Burt, supra note 94, at 371-73 (criticizing Roe).

107. Lincoln's First Inaugural Address (Mar. 4, 1861), reprinted in 1 DocumenTs of AMERICAN History 388 (H. Commager ed., 4th ed. 1948). 
unilaterally imposed surrender. That the South fought to preserve its own regime of involuntary servitude testifies to the paradoxical, tragic difficulties that recurrently obstruct the capacity of people to find a common language of mutual respect and obligation. But the Civil War also teaches that unless we honor this basic bond of persistent mutual engagement and obligatory dialogue as the means for this engagement, then each of us is truly alone and defenseless.

\section{V.}

The Supreme Court, in its current applications of the state autonomy principle, has not embraced this lesson. The Court's vision of states' rights and of the claim for individual autonomy from relations with others in its recent cases involving retardation and racial segregation treats the simple assertion of the wish to avoid association as intrinsically justified without any need to account for, or listen to, competing claims. ${ }^{108}$ Conflict between many disputing parties may in fact be so deep that an encompassing sense of community might never emerge, so that hostile separation is inevitable. But the current Court majority assumes this result too quickly. Its vision of autonomy does not give a fair opportunity to those who might persuade, who might touch the hearts of those who would otherwise abandon future relations with them.

In their hasty assumption, the Justices not only shut off the possibility that the disputants will learn about their deeper, previously unsuspected commonalities. The Justices also shut off the possibility that they will themselves learn this. These Justices thereby misconstrue the great purpose of the litigative process itself in our society: its embodiment of an ultimate ideal of a common humanity in the operating rule that litigation is open to anyone who feels aggrieved, that judges must listen and respond.

This misconstruction was the first great evil, the initial profanation, of the Dred Scott decision in the Supreme Court's ruling that black slaves could not be heard in federal courts because they were not citizens of the United States. ${ }^{109}$ This issue is also at the heart of the recent Supreme

108. The effort to enshrine this autonomy principle in constitutional doctrine is not limited to these cases; it has been a favorite project for Justice Rehnquist. See Powell, The Compleat Jeffersonian: Justice Rehnquist and Federalism, 91 YALE L.J. 1317 (1982). Justice O'Connor has more recently joined this enterprise. See FERC v. Mississippi, 456 U.S. 742, 775 (1982) (O'Connor, J., concurring in part and dissenting in part). It is not yet clear, however, that a solid majority of the present Court has coalesced to accept or to reject this effort. Compare National League of Cities v. Usery, 426 U.S. 833 (1976) (overturning congressional imposition of minimum wage for state employees) with EEOC v. Wyoming, $103 \mathrm{~S}$. Ct. 1054 (1983) (affirming congressional proscription of mandatory age-based retirement for state employees).

109. Dred Scott v. Sandford, 60 U.S. (19 How.) 393, 426-27 (1856). 
Court cases regarding retarded people. The basic question is not whether ordinary schools and residential neighborhoods must welcome retarded people or whether extraordinary tax resources must be allocated to them. The deeper question is whether there is any continuing obligation on socalled "normal" people to listen and respond to the claims of retarded people, and thereby to acknowledge at least this much shared humanity.

The cases involving retardation do not clearly present the same threat to social order that leap from the disputes between blacks and whites. The race disputes implicitly teach the lesson that secession-minded whites cannot simply walk away from blacks by a unilateral act of will, that whites cannot vindicate the secessionist principle unless blacks acquiesce by agreeing to let the whites live in peace. But does a similar lesson govern relations between normal and retarded people? The ostentatious dependency of institutionalized retarded people, their seemingly patent incapacity to care for themselves, suggests both that normal people can unilaterally sever relations and that social relations with retarded people rest on nothing but an unreciprocated act of grace. If neither the normal donor nor the retarded donee conceives of himself as participating in a reciprocating relationship, is there really an underlying communal relation between them? Even more significantly, can people utterly incapable of social exchange, such as those who are profoundly retarded, be part of a communal relation if, as I have suggested, dialogic engagement is the essential precondition for community?

Despite these apparent barriers, however, there are at least two ways that a communal relation can exist with even the most profoundly retarded person. Both ways paradoxically take root in the mind of only one participant in the exchange. The first, and perhaps more easily grasped, depends on hope-the optimistically imagined prospect that some future relation on some terms is possible, even with the most profoundly retarded person. In some circumstances, of course, this hope may seem wholly improbable to most observers. But this improbability does not diminish and may even intensify the hope of some people. This is a common attitude of many parents of retarded children and is reflected in their intense, prolonged efforts to elicit even the most minimal social responses from their children. ${ }^{110}$ This attitude most likely reflects an intensely felt identification of parent with child based on the fact of biological linkage, a tie that the parent does not view as severable by any unilateral act of will. When these parents demand that others view their children as they do, as disabled but potentially less so and, in any event, as fundamentally equal

110. See H. Featherstone, a Difference in the Family (1980); J. Greenfeid, A Child Galled Noah (1972); J. Greenfeld, A Place for Noah (1978); J. Murray \& E. Murray, And Say What He Is: The Life of a Spectal Ghild (1975); C. Park, The Siege (1967). 
participants in the human community, others can refuse this demand only by disparaging the deepest convictions of these parents and thereby denying the essential terms of a communal relationship with these parents.

This formulation depends on empathy-on parents' feeling for their child and others' regard for those parents. There is another way to consider relations with a profoundly retarded person that does not, however, so crucially depend on this benign, altruistic view. Hope is not the only wellspring from which mentally normal people can draw a conception of social relations with profoundly retarded people. Fear is another. This fear can grip parents and others as deeply as hope, and it can also distort rational capacities by creating a fantastic image of retarded people, even of the most remote and helplessly retarded person. This fear and the imagery it spawns may be irrational but they are nonetheless passionately real for those gripped by them. Thus consider these words written by Mr. Justice Holmes, upholding compulsory sterilization of mentally retarded people:

We have seen more than once that the public welfare may call upon the best citizens for their lives. It would be strange if it could not call upon those who already sap the strength of the State for these lesser sacrifices . . . in order to prevent our being swamped with incompetence. It is better for all the world, if instead of waiting to execute degenerate offspring for crime, or to let them starve for their imbecility, society can prevent those who are manifestly unfit from continuing their kind ... Three generations of imbeciles are enough. ${ }^{111}$

It is clear today that these fears were wildly exaggerated, as were beliefs in the biological heritability of retardation and its amenability to reproductive control. ${ }^{112}$ But the sense of vast threat from retarded people and the consequent embattled stance of Holmes and his contemporaries were real enough for them. If the threat of "degenerate . . . crime," of "being swamped with incompetence," did not come from retarded people, it must have come from the imaginations of those who viewed them. Perhaps Holmes and his contemporaries painted their darkest fears about themselves and their vulnerability in the world as they saw it onto the temptingly empty faces (as they saw them) of retarded people. From this perspective, it was not retarded people who were feared; they were not seen except for what they were fearfully imagined to represent.

This same projective process may be at work today, even in the more

111. Buck v. Bell, 274 U.S. 200, 207 (1927) (citation omitted).

112. See S. Gould, The Mismeasure of Man 146-74, 335-36 (1981); K. Ludmerer, Genetics aNd AMERIGan Society: A Historical. Appraisal 87-113 (1972) (noting links between eugenic sterilization laws and passage of the Immigration Restriction Act of 1924, ostensibly to protect American society from "race suicide" by influx of "biologically inferior" racial stock). 
benign contemporary attitude toward retarded people. Consider this indictment of institutional residence by the District Judge, Raymond Broderick, in the Pennhurst case:

At its best, Pennhurst is typical of large residential state institutions for the retarded. These institutions are the most isolated and restrictive settings in which to treat the retarded. Pennhurst is almost totally impersonal. Its residents have no privacy-they sleep in large, overcrowded wards, spend their waking hours together in large day rooms and eat in a large group setting. They must conform to the schedule of the institution which allows for no individual flexibility

The environment at Pennhurst is not conducive to normalization. It does not reflect society. It is separate and isolated from society and represents group rather than family living. ${ }^{113}$

Judge Broderick is undoubtedly correct in his portrayal of the harm this institution works on its residents. But I hear an added force behind these words, an attitude toward and fear of institutions that is not restricted to their impact on retarded people. I hear this force in one aspect of the judge's indictment that is surely wrong: his conclusion that Pennhurst "does not reflect society." It does reflect society-the frightening aspects, that is, of contemporary American society in its impersonality, its threats to individual privacy, its demands for conformity "which allow for no individual flexibility." Retarded residents of Pennhurst are more patently afflicted by these institutional characteristics, more obviously disabled from developing their capacities for self-sufficiency than ordinary people. But Pennhurst is nonetheless a nightmare reflection of the powerful social constraints on anyone's capacity to achieve self-sufficient autonomy.

An echo of this same nightmare accompanies the newly adamant claims of handicapped people generally in public forums. Their claims are for rights to independence, to self-respect, and to self-sufficiency. But these claimed rights contain the implicit acknowledgement that handicapped people cannot vindicate their claims without others' assistance. 'This needed assistance may involve others' financial resources (as in tax support for special educational resources or for wheelchair ramps into public facilities ${ }^{114}$ ); it may involve others' emotional resources (as in families' devotion or neighbors' tolerance for the appearance of handicapped people

113. Halderman v. Pennhurst State School \& Hosp., 446 F. Supp. 1295, 1303, 1311 (E.D. Pa. 1977) (citations omitted), aff'd in part and rev'd in part, 612 F.2d 84 (3d Cir. 1978), rev'd, 451 U.S. 1 (1981).

114. See 20 U.S.C. $\$ \S 1401-20$ (1976) (free public education for all handicapped children); 42 U.S.C. $\$ \S 4151-57$ (1976) (public facilities access). 
as residents in their community). It is thus paradoxical that handicapped people must depend on others' assistance in order to achieve their goal of independence from others. But in this paradoxical dependence, handicapped people resemble everyone who, in striving for independent autonomy, is nonetheless constrained by an inescapable economic and social network of interrelated dependencies-everyone, that is, in America today.

To see fears that afflict most people, "normal" people, in the injuries claimed by handicapped people does not disprove the reality of those injuries. To see a pervasive fear of institutional depersonalization in contemporary American society as adding intensity to Judge Broderick's wish to close down Pennhurst does not show the error of this course. I draw these linkages for a more limited purpose, to suggest that this kind of projective identification itself significantly shapes the conception of a social relationship. The claims of physically handicapped people may owe their recent visibility and salience to widespread (and newly intense) fears among able-bodied people about personal independence and vulnerability, fears that may have provided the first words in a newly evolving mutual vocabulary between able-bodied and handicapped people. But active dialogue is not the only way that this language can take shape. A conception of a relationship can occur in the mind of only one participant. A relationship can thus arise even with the most profoundly, the most remote and uncommunicative retarded person. Indeed, the very remoteness of this person can feed the image of a relationship that arises from a belief and fear that interpersonal isolation is a characteristic affliction of our time. ${ }^{115}$

Assuming that this speculation is correct, it might appear that a communal relationship between the "normal" majority and the handicapped minority would find its own adequate expression in majoritarian legislative institutions without the need for a special judicial role. But this does not follow. The fear that produces the conception of the relationship can have an added paradoxical quality that leads those in its grip to deny its force in their own minds, to wish that they could banish this fear and its imagined embodiment in this alien "other" by a unilateral act of will. For retarded people, the social history of the origins and expansive use of isolated institutions testifies to the power of this wish. ${ }^{116}$ This impulse to isolate and abuse the embodied expression of one's own fears can take many forms. Whatever the form, this impulse is a kind of internal war-

115. See R. Burt, Taking Care of Strangers: The Rule of Law in Doctor-Patient Relations 144-73 (1979) (discussing psychological forces that ascribe fearful communication to seemingly silent people, such as comatose or profoundly retarded).

116. See Wolfensberger, The Origin and Nalure of Our Institutional Models, in Ghanging Patterns in Residential Services for the Mentally Retarded 88-129 (R. Kugel \& W. Wolfensberger eds. 1969). 
fare, a struggle denoted, for example, by Justice Holmes's embattled words.

A legislative vote or a public opinion poll might readily demonstrate whether many Americans perceive a fundamental similarity between handicapped and "normal" people. But no poll could reliably probe the question whether some or many or most people darkly glimpse this similarity but recoil from acknowledging it as a fearful possibility. Fateful consequences would follow for any group or individual caught in this conceptual bind. They would avoid contact or any acknowledgement of a potentially reciprocal relationship with handicapped people, and yet, at the same time, this stance would seem precarious since they were not only avoiding handicapped people but running from that part of themselves which suggested a common identity with handicapped people. This effort to sever relations with the handicapped is thus an exhausting-literally self-defeating-pursuit. These people are not so much at war with handicapped people (though they can readily be tempted to wage quite brutal warfare against them, in large residential institutions and elsewhere). These people are more fundamentally at war with themselves, with their divided selves. This inner division, this ambivalence, could lead these people vociferously to deny any common bond with handicapped people at the same time that they unconsciously believed in, but recoiled from acknowledging, that bond.117 Actions of majoritarian institutions based on these attitudes toward handicapped people lack an adequate consensual base, but not because handicapped people themselves might oppose these policies. This consensual basis is lacking because the "normal" majority is divided within itself. The diametric opposition that robs public policy of legitimacy can thus be found in the minds of one party to an imagined relationship, in the ambivalence and fear of the majority who voted for that policy.

It is, of course, not clear whether or to what extent this fear dominates contemporary public policy toward handicapped people. But its plausibility is, I believe, sufficient to justify a court's acting to test the hypothesis, to prove or disprove it. This proof cannot come through judicial factfinding in its conventionally conceived sense. This proof can only come through a prolonged process in which judges lead others (litigants and those who witness litigation) to confront and answer for themselves the question whether they truly see themselves as free to deny any communal bond with handicapped people. ${ }^{118}$ This confrontational process, this insis-

117. See generally R. BuRT, supra note 115, at 61-71, 169-72 (discussing psychological dynamics of ambivalence toward apparently powerless people).

118. For consideration of the ways this role conception should guide judges generally in litigation challenging the treatment of retarded people by large-scale bureaucracies, such as residential institu- 
tence on a prolonged dialogue, is the methodology that I have identified as characteristic of the parables and the race cases. This methodology is not irrelevant because one party appears disabled from active participation-because, for example, one is profoundly retarded. In this context, the necessary dialogic engagement takes place in one divided mind.

This, then, is the pedagogic role that I see for courts regarding the status of the handicapped people in our society-to honor hope (of these people or their parents or others) for their inclusion in a fully communal relationship and to confront fear that may shut them away from such an acknowledged relationship. This role should guide courts in specific cases. In its recent decisions, however, the Supreme Court has lost sight of this role.

In Youngberg $v$. Romeo, ${ }^{119}$ damages were claimed against state officials for a profoundly retarded Pennhurst resident because staff and other residents had repeatedly injured him, tied him in restraints for prolonged times, and failed to provide him with a training program. The district court ruled that the failure to provide this training program did not present a claim of constitutional right; ${ }^{.20}$ the Supreme Court reversed this ruling, holding that Pennhurst must provide at least the "minimally adequate or reasonable training" likely to promote Romeo's capacity for selfcontrol. ${ }^{121}$ In effect, the Court required communal efforts to enhance the possibility of some minimal social relation with this most profoundly retarded person, even if this communal effort was nothing more than trying to teach Nicholas Romeo to control his aggressive impulses so that he would not frighten others and provoke them to abuse him or cage him like a wild animal. ${ }^{122}$ This is a limited conception of a social relationship, but it is nonetheless fundamentally different in principle and in practice from the unadorned custodial purposes of Pennhurst and other traditional state retardation institutions.

The lesson of community is thus clearly at work in the Court's decision in Youngberg $v$. Romeo. The Court had misunderstood this lesson, however, in its decision the preceding Term in Pennhurst $v$. Halderman. ${ }^{12 s}$ The constitutional rights of retarded people were not directly at issue in

tions or public schools, see Burt, Pennhurst: A Parable, in IN THE INTEREsts of CHILDREN: AdvoCacy, Law Reform, and Public Policy (R. Mnookin ed.) (forthcoming).

119. 457 U.S. 307 (1982).

120. See Romeo v. Youngberg, 644 F.2d 147, 155-56 (3d Cir. 1980) (rejecting district court's standard of "deliberate indifference to the serious medical needs of the resident").

121. 457 U.S. at 319.

122. The Supreme Court pointedly left open the question whether the Constitution requires state institutions to engage in more intensive training efforts to promote the self-sufficiency of their residents; the Court found that Romeo's complaint had not sought this more intensive treatment program. Id. at 317-18.

123. Pennhurst State School \& Hosp. v. Halderman, 451 U.S. 1 (1981). 
Pennhurst; the question was whether Congress had recognized the rights of institutionalized retarded people to intensive treatment programs generally and to community residential placement specifically. The Court ruled that, though Congress had spoken of such rights in a 1975 act, this invocation was only "hortatory, not mandatory" on the states. ${ }^{124}$

Dissenting Justices strenuously argued that this misread the true intent of the statute. ${ }^{125}$ I would argue a somewhat different proposition-that even if the 1975 Act were ambiguous on this score, the Court should have construed this ambiguity in favor of imposing obligations for treatment and community placement on the states. The Court's fundamental misunderstanding of its proper role in these disputes was not so much in its reading of this statute as in the enunciated canon of statutory construction that led to this reading. Justice Rehnquist wrote that Congress must speak "unambiguously" before the Court would construe the Act as imposing any obligation upon the states regarding services for retarded people. He asserted that this was a traditional matter of state sovereignty and that therefore congressional impositions were at least constitutionally suspect if not prohibited altogether. ${ }^{126}$ Justice Rehnquist invoked this same interpretive canon in the service of a similarly parsimonious reading of congressional intent the succeeding Term in Board of Education v. Rowley, ${ }^{127}$ holding that the mandate in another congressional act for "free appropriate public education" for all handicapped children did not require a full-time sign language interpreter for a deaf child. ${ }^{128}$

Whichever way the Court chose to construe the statute at issue in these cases-whether for or against a more inclusive communal relation-the Congress could enact a new law unambiguously expressing a contrary intent. ${ }^{120}$ The practical force of legislative inertia, however, always gives

124. Id. at 24 .

125. Id. at 34-41 (White, J., dissenting) (joined by Brennan \& Marshall, JJ.) (Congress intended Developmentally Disabled and Bill of Rights Act to serve as requirement that participating states must observe to receive federal funds).

126. Id. at 17 .

127. 458 U.S. 176 (1982).

128. Id. at 209-10. The school board had refused to provide an interpreter for several reasons: It would be extraordinarily expensive $(\$ 20,000$ to $\$ 25,000$ each year, according to its estimates), the board was already providing some compensatory services, and the child was learning well enough (though she nonetheless missed hearing about half of what transpired in the classroom). N.Y. Times, Mar. 24, 1982, at B1, col. 1, B4, col. 5. The child was represented in the Supreme Court by an attorney who was himself deaf; the Court broke precedent by permitting a stenographer to type out the Justices' questions and opposing counsels' argument so that the attorney could respond to them. Id.

129. Indeed, the 1975 Act at issue in Pennhurst expired by its own terms on July 1, 1981, less than four months after the Supreme Court's ruling. See Rehabilitation, Comprehensive Services, and Developmental Disabilities Act Amendments of 1978, Pub. L. No. 95-602, 92 Stat. 3007 (1978). Thus, any judicial construction of the Act in that case would necessarily have received virtually immediate congressional consideration, whether for ratification or rejection by action or inaction. 
some staying power to the current law. ${ }^{130}$ In construing ambiguous statutory language, the Court can properly pursue its pedagogic purposes by allocating this advantage. If, as I have argued, the Court should favor the communal principle, then Justice Rehnquist's interpretive canon is wrong. This canon's general deference to state autonomy and its specific application in Pennhurst and Rowley against the claims of handicapped people favor the secessionist error.

The Justices committed this error in another way in Pennhurst. The Court of Appeals found that in enacting the Bill of Rights provisions of the 1975 Act, Congress had intended to invoke its authority to enforce the Fourteenth Amendment. ${ }^{181}$ The appellate court concluded that judges should therefore defer to this congressional finding that the Constitution guaranteed to retarded people "a right to appropriate treatment" generally, and specifically the provision of that treatment "in the setting that is least restrictive of [their] personal liberty," that is, in ordinary community settings. ${ }^{132}$ The Supreme Court ruled, however, that Congress had not exercised this authority because it had not unambiguously expressed such intention in the text of the statute itself. ${ }^{138}$ This, too, was a mistake. Even accepting the premise that congressional intent was unclear here, the Court should have welcomed and reached out to find Congress's constitutional interpretive authority in this matter.

When Congress deliberated the 1975 Act, several federal district courts had already conducted extensive hearings on conditions in state retardation institutions and had found brutal degradations. These courts had ruled that constitutional rights were thereby violated but they differed in prescribing remedies, some restricting attention to institution-based improvements and others pressing for greater use of community facilities. ${ }^{134}$ The 1975 Act plausibly-I would say most plausibly-reflected a general congressional endorsement of these judicial findings that institutional conditions violated constitutional rights, a directive that increased use of community facilities has some important role in correcting these violations, and a commitment of federal funds and executive enforcement power to this corrective purpose. ${ }^{135}$ The Act thus appears to offer a collaboration

130. See G. Calabresi, a Common Law for the Age of Statutes 6, 101-03 (1982).

131. Halderman v. Pennhurst State School \& Hosp., 612 F.2d 84, 98 (3d Cir. 1979), rev'd, 451 U.S. 1 (1981).

132. Id. at 106 (quoting H.R. Conf. Rep. No. 473, 95th Cong., 1st Sess. 41-42 (1975)).

133. 451 U.S. at 15-17.

134. Compare Wyatt v. Stickney, 344 F. Supp. 387 (M.D. Ala. 1972) (Constitution requires minimum levels of care and training at state institution for mentally retarded people), aff'd in part and rev'd in part, 503 F.2d 1305 (5th Cir. 1974) with New York State Ass'n for Retarded Children v. Carey, 393 F. Supp. 715 (E.D.N.Y. 1975) (approving consent judgment which included goal of developing community facilities and substantially reducing population of state retardation institution).

135. The relevant portion of the Act is $\$ 6010$ : 
between Congress and the courts in addressing problems of inhumane conditions in state retardation institutions. The Supreme Court's Pennhurst decision in effect spurned this offer.

The Court's more recent opinion in Youngberg $v$. Romeo acknowledged the brutality of these institutions and held that constitutional rights were thus violated. But the Court invoked only its own authority in this holding. The Court did not only miss the opportunity the previous Term, in Pennhurst, to buttress judicial authority in these matters. More fundamentally, the Court failed to understand or admit that its isolated authority was insufficient to remedy any of these institutional problems; the Court failed to see that unless it could enlist the active assistance of many others, it could not effectively protect Nicholas Romeo and those like him.

This judicial incapacity comes from more than the inherent enforcement weaknesses of courts in our constitutional scheme. It comes more pointedly from the special features of litigation aimed at abuses of largescale bureaucratic institutions. A judge may find abuses and want to correct them. But who in a diffuse bureaucracy is responsible for the wrongdoing? Who has clear internal authority and sufficient command of resources to undo the wrongs? Who is available and sufficiently attentive to police the bureaucracy's future compliance in its dealings with those inescapably caught within it? Unless the judge can enlist the assistance of many others, including, ultimately, at least the grudging acquiescence of a significant number of officials and employees within the challenged bureaucracy itself, the judge will talk to the wind in his injunctions. ${ }^{138}$ Congress has greater power over state institutions; it has direct command of federal funds and executive enforcement personnel, and it has the moral and political force of its popular mandate. The Supreme Court could benefit greatly from the assistance of this congressional power to enforce even its limited directive to state institutions in Romeo; it had the offer in hand in Pennhurst.

Congress makes the following findings respecting the rights of persons with developmental disabilities:

(1) Persons with developmental disabilities have a right to appropriate treatment, services, and habilitation for such disabilities.

(2) The treatment, services, and habilitation for a person with developmental disabilities should be designed to maximize the developmental potential of the person and should be provided in the setting that is least restrictive of the person's personal liberty.

(3) The Federal Government and the States both have an obligation to assure that public funds are not provided to any institution[] . . . that-

(A) does not provide treatment, services, and habilitation which is appropriate to the needs of such persons; or

(B) does not meet the following minimum standards . . . .

Developmentally Disabled Assistance and Bill of Rights Act, 42 U.S.C. $\S 6010$ (1976 \& Supp. V 1981).

136. See Diver, The Judge as Political Powerbroker: Superintending Structural Change in Public Institutions, 65 VA. L. REv. 43, 99-103 (1979); Starr, supra note 94, at 438-39. 
The Court's enforcement problems are not unique to residential institutions for retarded people. These problems are endemic to its attempts to influence any of the large-scale bureaucracies that dominate contemporary social life. The Court most dramatically encountered these problems in its efforts to alter racial segregation practices in the South. Even before the Court grappled directly with public school segregation, it had repeatedly addressed racial discrimination in law enforcement ${ }^{137}$ and in voting practices $^{138}$ and had found itself lacking effective power. The Court's experience after Brown reinforced this lesson. ${ }^{139}$ When Congress lent its force to the Court's commands-tentatively in the 1957 Civil Rights Act and then resoundingly in the 1964 and 1965 Acts-Southern compliance increased exponentially. ${ }^{140}$ The Court drew on this experience in 1966 when it decided that Congress had independent authority to interpret the Fourteenth Amendment. In this decision, Katzenbach $v$. Morgan, ${ }^{141}$ the Court meant to welcome and encourage the active collaboration of Congress in accomplishing the communitarian goals of Brown. ${ }^{142}$ The Court's recent crabbed application of the Morgan doctrine in the service of "state autonomy" signifies a considerable failing in its vision.

The Court's failure to acknowledge its own institutional dependence in Pennhurst and Romeo extends beyond these particular cases. The Court's isolated vision of its own institutional role and authority is one aspect of its pervasive blindness to the fact and to the implications of interdependence in all social relations. Its conception of states as autonomous actors in our federal system, rather than as necessarily interdependent with the national government, is another aspect. The Court's attitude toward race

137. See, e.g., Hale v. Kentucky, 303 U.S. 613 (1938) (systematic exclusion of blacks from jury lists violates equal protection clause); Powell v. Alabama, 287 U.S. 45 (1932) (court must appoint counsel for felony defendant, in part to allow challenges to discriminatory jury selections).

138. See, e.g., Nixon v. Herndon, 273 U.S. 536 (1927) (invalidating statute excluding blacks from voting in Texas primary elections); Nixon v. Condon, 286 U.S. 73 (1932) (same); Smith v. Allwright, 326 U.S. 649 (1944) (same).

139. See Gewirtz, Remedies and Resistance, 92 Yale L.J. 585, 636 n.133 (1983) (discussing resistance of school boards to integration).

140. In the $1960-61$ school year, only $6.4 \%$ of black students in the seventeen states classified as Southern attended school with any white students; this figure had increased to 39.6\% by the 1968-69 school year and to $84.3 \%$ by the 1970-71 school year. U.S. Bureav of THE CENSUS, STATISTICAL ABSTRACT OF THE. UNITED STATES 124 (1974). Compare this observation by the Court of Appeals for the Fifth Circuit: "The only school desegregation plan that meets constitutional standards is one that works . . . A national effort, bringing together Congress, the executive, and the judiciary may be able to make meaningful the right of Negro children to equal educational opportunities. The courts acting alone have failed." United States v. Jefferson County Bd. of Educ, 372 F.2d 836, 847 (5th Cir. 1966) (emphasis in original).

141. 384 U.S. 641 (1966).

142. See United States v. Guest, 383 U.S. 745, 784 (1966) (Brennan, J., concurring in part and dissenting in part); Harper v. Virginia Bd. of Elections, 383 U.S. 663, 679-80 (1966) (Black, J., dissenting); Bell v. Maryland, 378 U.S. 226, 343 (1964) (Black, J., dissenting); see also Burt, Miranda and Tille II: A Morganatic Marriage, 1969 SuP. Gr. REv. 81, 110-11, 113 n.120, 118. 
relations, its willingness to ratify rather than to resist contemporary separatist impulses, is yet another. In all of these matters, the Court should instead offer a vision that might lead others to see themselves clearly as members of a single, interdependent, and mutually supportive community.

The pedagogic strategy that the Court should follow in holding out this vision cannot be reduced to any simple formula. Both the proper occasions for initial judicial intervention in any particular dispute and the persistence of courts in reopening repeated majoritarian resolutions of these disputes will depend on many complicated considerations. The underlying goal in all cases is for the Court to ensure that anyone's claim for inclusion in a communal relation receive sustained, serious attention from all others.

\section{VI.}

There is considerable room for difference of opinion in discerning the proper occasions for judicial intervention. It can be argued in race relations, for example, that contemporary patterns of intertwined racial and economic barriers reflect the conclusion of a long, hard-fought social deliberative process provoked by the Court a generation ago. I would argue, however, that though these relations now seem settled, and though they differ significantly from the communal race relations that prevailed before Brown, the fearful social consequences of current patterns are not truly understood or widely acknowledged. I therefore see an important contemporary judicial role toward this end.

But even if judicial intervention in racial matters has run its proper course for now, the courts have not focused equivalent, sustained attention on the claims and status of handicapped people in our society. Lower federal courts made an important beginning during the past decade, and Congress spoke significantly in the two 1975 Acts. But the Supreme Court has thus far misunderstood these voices and its own proper role in this question. Of course social resources are scarce; of course the claims of handicapped people conflict with the claims of others to keep their scarce resources for themselves; of course there is considerable prospect that these conflicting claims will end in irreconcilable and openly hostile conflict. Courts should nonetheless hold out the possibility for sustained serious deliberation that these claims are not truly in conflict, that as the father in the parable suggested to his elder son, the return of these lost brothers will be an occasion for rejoicing because everyone will have regained a lost part of himself.

Courts in our constitutional scheme can play a significant role in giving life to this aspiration, in repeatedly resurrecting it from apparent defeats inflicted in majoritarian institutions. Ultimately this is the great gift that 
the institution of judicial review offers our society-the opportunity for a majority to undo an action the consequences of which appear, as Chief Justice Stone put it, on "sober second thought"14s to harm the majority and the minority, the perpetrator and the victim. The majority will make good use of this gift only if, when forced to this "sober second thought," it finds more in common with the previously defeated minority than it had been prepared to acknowledge. If the majority finds this, it will then seek to affirm this common ground rather than to reiterate its previous subordination of the minority. Judges cannot force this result; but by identifying the values impeached by the majority's prior action and by forcing the majority to reconsider its action in the light of those values, judges can lead the majority toward embracing this result.

This was the ultimate pedagogic goal of the father toward his elder son in the prodigal son parable. The father invoked his authority only to demand that this son consider the possibility that he had more reason to welcome than to regret his brother's return. He left it for the elder son to discover the truth of this conclusion for himself. But though the father did not spell out the reasons, the elder son could find them if he accepted the premise that he and his brother shared a common interest-that both were barred from finding a haven unless each was willing to embrace the other. And once he had seen this identity of interest with his brother, the elder son might also see his own true identity.

The father did not openly assert the true identity of his elder son nor does the parable explicitly reveal this for the listener or the reader, but there are many hints in the parable that the elder son was in fact Cain, who had once murdered his younger brother Abel. In the Old Testament, Cain was impelled to murder after God had favored Abel's offerings of the "fat portions" of slaughtered lambs and had rejected Cain's offerings of produce. Then "Cain was very angry, and ... said to Abel his brother, 'Let us go out to the field.' And when they were in the field, Cain rose up against his brother Abel, and killed him." God then condemned Cain to "be a fugitive and a wanderer on the earth."144 In the prodigal son parable, the elder son was "in the field" when he first appeared in the narrative and when he later complained of his father's favoritism in killing the "fatted calf" to welcome his brother. The New Testament parable thus suggests that the younger son Abel has been brought back to life-he "was dead, and is alive; he was lost and is found"145 - so that the elder son Cain is given the chance to end his own fugitive status and return home. But he can grasp this opportunity to repent, this chance for a

143. Stone, The Common Law in the United States, 50 HaRv. L. REv. 4, 25 (1936).

144. Genesis 4:4-12 (Revised Standard).

145. Luke 15:32 (Revised Standard). 
"sober second thought," only if he understands and acknowledges both his true identity and the wrongfulness of his past inflictions on his brother. ${ }^{148}$

The father did not force this lesson on the elder son in the New Testament parable. It is hidden, embedded in the narrative of the parable. The elder son could find this lesson only if he exerted effort to search for it. But if he discovered it, and saw how directly it applied to him, then he would have clear reason to rejoice at his younger brother's return, for this would now mark the end of his own wandering and permit his own safe return home.

The parable thus gives the same opportunity for repentence, for "sober second thought" regarding the fraternal infliction of harm, to which Chief Justice Stone referred in his characterization of the function of judicial review. Like the father in the parable, judges cannot force anyone to take advantage of these opportunities. But like the father, judges can and must show how these opportunities for communal reconciliation might be grasped. When judges understand this lesson, then they can force others to attend to its truth in the same way that Jesus commanded attention when he told his first parable: "Listen! . . . If you have ears to hear, then hear."147

146. This reiteration of the Genesis account of the first murder in the prodigal son parable is characteristic of the relationship between much of the Old and New Testaments. See N. FRYE, THE Great Code: The Bible and Literature 78-79 (1982).

147. Mark 4:3-9 (New English). 
HeinOnline -- 93 Yale L.J. 503 1983-1984 


\section{The Yale Law Journal}

Volume 93, Number 3, January 1984

John K. Setear

Thomas A. Smith

Note $\mathcal{E}$ Topics Editor

Kathryn R. Abrams

Dean M. Hashimoto

Daniel C. Richman

Stephanie I. Splane

Note Editors
C. Cabell Chinnis, Jr.

Managing Editor

Robert R. Harding

Pamela S. Karlan

Eben Moglen

Stefan R. Underhill

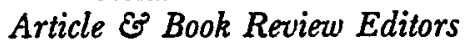

Senior Editors

Eric O. Corngold

Stephen E. Creager

Joseph A. Franco

Michael R. Hepworth

Bruce D. Judson

Mercedes A. Laing

\author{
Paul G. Mahoney \\ Stephen J. Massey \\ Michael B. Rappaport \\ Jefferey M. Sellers \\ Thomas R. Webb \\ Steven J. Weingarten
}

Editors

Akhil R. Amar

Steven A. Baronoff

Stuart E. Bauchner

Daniel M. Bodansky

Louis M. Bograd

Reuben C. Cahn

Vikram K. D. Chandhok

Brent M. Cohen

Lawrence P. Fletcher

Theresa Glennon
Daniel J. H. Greenwood

Michael O. Hill

Patricia A. Krieg

Myles H Kuwahara

Debra L. Lagapa

Patrick A. Malone

Emily McKillip

Barbara E. Pace

Michael A. Paulsen

Anne Marie Pecht
Clifford L. Rechtschaffen

Stuart P. Rosenthal

Michael H. Schill

Eileen F. Serene

Liang-Houh Shieh

Susan Lynn Stewart

Kent T. Van den Berg

Henrietta Wright

Ronald F. Wright, Jr.

Rob G. Zeitinger

Business Manager: Pamela Standish Editorial Assistant: Claudia Shapiro

\section{Student Contributors to This Issue}

Lawrence P. Fletcher, Restitution in the Criminal Process: Procedures for Fixing the Offender's Liability

Paul G. Mahoney, A Market Power Test for Noncommercial Boycotts

Stephen J. Massey, Justice Rehnquist's Theory of Property

Thomas A. Smith, The Rule of Law and the States: A New Interpretation of the Guarantee Clause 